\title{
Distribution and Biology of Grenadiers (Macrouridae) in West Greenland Waters
}

\author{
Ole A. Jørgensen \\ Greenland Institute of Natural Resources, Tagensvej 135, \\ DK-2200 Copenhagen N, Denmark
}

\begin{abstract}
During the period 1987-94, 11 bottom trawl surveys covering depths from 34 to 1497 $\mathrm{m}$ were conducted at West Greenland. Two grenadier species not previously recorded for the area, Nezumia bairdi and Gadomus longifils, were caught bringing the number of species recorded in West Greenland waters to ten. A significant amount of new information on grenadier species previously recorded was also collected during the surveys. Geographic distribution in relation to depth and temperature, abundance of the most common species, Coryphaenoides rupestris, Coryphaenoides güentheri and Macrourus berglax and length distributions of all species encountered were analyzed. Growth of $C$. rupestris and M. berglax, food of $C$. rupestris, $M$. berglax (in relation to time of the year and predator length), C. güentheri and Coryphaenoides brevibarbis, length/weight relationships for C. rupestris, C. güentheri and $M$. berglax are also presented. Further, relationships between total length and pre-anal fin length for Trachyrhynchus murrayi and all species mentioned above, except $G$. longifilis, and maturation of $C$. rupestris and $C$. güentheri are given. The available information about three grenadier species not observed during the surveys but previously recorded from the area, i.e. Nezumia aequalis, Coryphaenoides armatus and Coryphaenoides carapinus, is summarized.
\end{abstract}

Key words: Distribution, food, grenadiers, length, maturation, weight, West Greenland

\section{Introduction}

The family Macrouridae is rich in species and representatives are found in most oceans. Macrourids are generally benthopelagic occurring at considerable depths on the continental slopes and the abyssal planes. Knowledge of the distribution and biology of most species is meager due to the great depths they inhabit.

During the period 1987-94, a number of trawl surveys in West Greenland waters were conducted covering depths down to $1497 \mathrm{~m}$. This has added significantly to our knowledge of macrourid species in West Greenland waters and has revealed two previously unrecorded species; Nezumia bairdi and Gadomus longifilis. The present paper also presents information on the distribution and a number of biological characteristics of five other species observed during the surveys; Coryphaenoides rupestris, Coryphaenoides güentheri, Coryphaenoides brevibarbis, Macrourus berglax and Trachyrhynchus murrayi, and reviews the available information on three species previously recorded from West Greenland but not encountered during these surveys; Coryphaenoides carapinus, Coryphaenoides armatus and Nezumia aequalis (Jensen, 1948; Karrer, 1976).

The survey area was bounded on the west by the midline between Canada and Greenland. This is a politically defined boundary without any biological sense. Species such as $C$. rupestris (Atkinson, 1995) and M. berglax (Savvatimsky, 1989b; Atkinson and Power, MS 1987) are certainly found west of the midline and a number, if not all, of the species found on the West Greenland side of the boundary are likely to also occur west of the midline.

\section{Materials and Methods}

Data and material were collected during 11 bottom trawl surveys which were directed mainly at Greenland halibut (Reinhardtius hippoglossoides). The surveys were conducted from 1987 to 1994 at different times between April and December (Table 1). A total of 945 trawl hauls were carried out.

The surveys were conducted at West Greenland from south of Cape Farewell $\left(59^{\circ} 27^{\prime} \mathrm{N}\right)$ to $72^{\circ} 51^{\prime} \mathrm{N}$, between the 3-mile boundary line and the 200-mile line or the midline between Canada and Greenland, at depths from 34 to $1497 \mathrm{~m}$. The NAFO Div. 1C and 1D were covered by all surveys except one, while areas north of $69^{\circ} 57^{\prime} \mathrm{N}$ and south of $63^{\circ} 03^{\prime} \mathrm{N}$, were only covered once; the latter area down to 998 m depth only (Table 1, Fig. 1).

All surveys were carried out by the Japanese research vessel SHINKAI MARU, a 3395 GRT stern 
TABLE 1. Number of hauls, period, depth range and area covered in the surveys conducted.

\begin{tabular}{|c|c|c|c|c|}
\hline Date & $\begin{array}{c}\text { Number of } \\
\text { hauls }\end{array}$ & $\begin{array}{c}\text { Area covered } \\
\text { in NAFO }\end{array}$ & & $\begin{array}{l}\text { Depth range } \\
(\mathrm{m})\end{array}$ \\
\hline $15 \mathrm{Jul}-13$ Aug 1987 & 117 & $59^{\circ} 27^{\prime} \mathrm{N}-69^{\circ} 57^{\prime} \mathrm{N}$ & $1 F-1 A$ & $34-998$ \\
\hline 12 Sep - 11 Oct 1988 & 109 & $63^{\circ} 06^{\prime} \mathrm{N}-72^{\circ} 51^{\prime} \mathrm{N}$ & $1 D-1 A$ & $259-1402$ \\
\hline 30 Apr - 17 May 1989 & 61 & $63^{\circ} 03^{\prime} \mathrm{N}-65^{\circ} 43^{\prime} \mathrm{N}$ & $1 \mathrm{D}-1 \mathrm{C}$ & $494-1497$ \\
\hline 09 Jun - 22 Jun 1990a & 75 & $63^{\circ} 05^{\prime} \mathrm{N}-68^{\circ} 26^{\prime} \mathrm{N}$ & $1 \mathrm{D}-1 \mathrm{~B}$ & $449-1482$ \\
\hline 27 Aug - 12 Sep 1990b & 87 & $63^{\circ} 11^{\prime} \mathrm{N}-69^{\circ} 42^{\prime} \mathrm{N}$ & $1 D-1 A$ & $422-1467$ \\
\hline 04 Aug - 30 Aug 1991a & 139 & $63^{\circ} 07^{\prime} \mathrm{N}-69^{\circ} 57^{\prime} \mathrm{N}$ & $1 D-1 A$ & $38-1490$ \\
\hline 12 Nov - 27 Nov $1991 b$ & 51 & $66^{\circ} 21^{\prime} \mathrm{N}-69^{\circ} 57^{\prime} \mathrm{N}$ & $1 \mathrm{~B}-1 \mathrm{~A}$ & $38-774$ \\
\hline 11 Aug - 28 Aug 1992a & 90 & $63^{\circ} 04^{\prime} \mathrm{N}-69^{\circ} 45^{\prime} \mathrm{N}$ & $1 D-1 A$ & $417-1475$ \\
\hline 25 Nov - 07 Dec 1992b & 49 & $63^{\circ} 10^{\prime} \mathrm{N}-66^{\circ} 11^{\prime} \mathrm{N}$ & $1 \mathrm{D}-1 \mathrm{C}$ & $510-1400$ \\
\hline 20 Aug - 08 Sep 1993 & 87 & $63^{\circ} 11^{\prime} \mathrm{N}-68^{\circ} 25^{\prime} \mathrm{N}$ & $1 \mathrm{D}-1 \mathrm{~B}$ & $435-1418$ \\
\hline 02 Aug - 19 Aug 1994 & 80 & $63^{\circ} 08^{\prime} \mathrm{N}-68^{\circ} 21^{\prime} \mathrm{N}$ & $1 \mathrm{D}-1 \mathrm{~B}$ & $439-1472$ \\
\hline
\end{tabular}

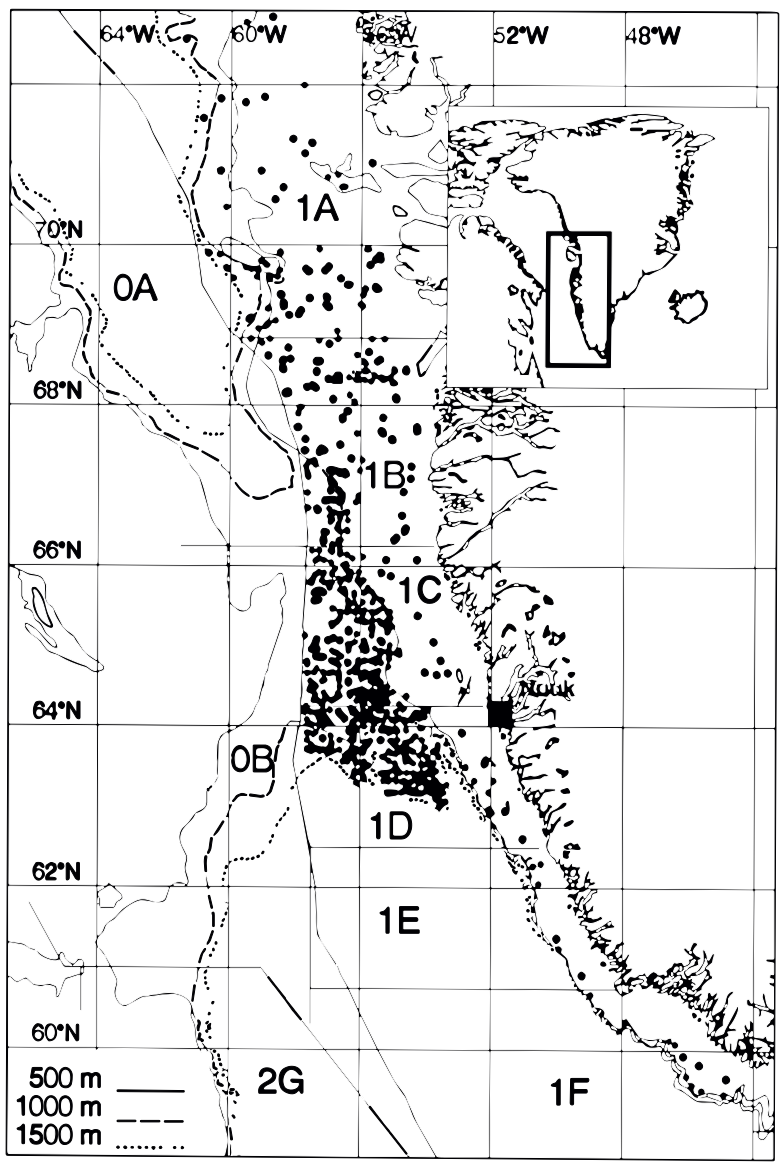

Fig. 1. Distribution of hauls in 11 bottom trawl surveys conducted in the period 1987-94.

trawler with $5000 \mathrm{HP}$. Towing time was $30 \mathrm{~min}$ and towing speed 3.5 knots. The trawl wingspread and net height were $40 \mathrm{~m}$ and $7.5 \mathrm{~m}$, respectively, and the mesh size was $140 \mathrm{~mm}$ with a $30 \mathrm{~mm}$ mesh codend liner.
After each haul, the catch was sorted by species and weighed to the nearest $0.1 \mathrm{~kg}$. The number of specimens were recorded, and in most cases the length was measured as pre-anal fin length (AFL) (from the tip of the snout to the basis of the first anal fin ray) to $0.5 \mathrm{~cm}$ below. In order to make comparisons of abundances and length frequencies of $M$. berglax between surveys and areas possible, Div. $1 \mathrm{~A}$ (south of $70^{\circ} \mathrm{N}$ ) and $1 \mathrm{~B}$, and Div. $1 \mathrm{C}$ and $1 \mathrm{D}$ were combined as a northern and as a southern area, respectively. Surveys or areas with less than 10 records of $M$. berglax were excluded from the analysis, i.e. Div. 1 A north of $70^{\circ} \mathrm{N}$ in 1988 , Div. 1B in the first survey in 1990 and the second survey in 1991. No observations were made at depths between $38-400 \mathrm{~m}$ in Div. $1 \mathrm{~A}$ and $1 \mathrm{~B}$ in the first survey in 1991, and this depth range was also excluded from the analysis (Table 1). Only data from depths $>400 \mathrm{~m}$ were thus included in the analysis.

A number of specimens with unbroken tails were measured as total length (TL) (to $1.0 \mathrm{~cm}$ below), in order to obtain relationships between AFL and TL. Analyses of covariance were carried out to test the null hypothesis that no difference existed between the slopes or intercepts of the separate relationships for males and females (C. rupestris $(n=658), M$. berglax $(n=498)$ and $C$. güentheri $(n$ = 752)). Linear regression analyses (Anon., 1985) were then carried out to derive relationships between AFL and TL by sex (C. rupestris, the only species with significant difference between sexes) and for sexes combined (C. güentheri, $C$. brevibarbis $(\mathrm{n}=24), M$. berglax, T. murrayi $(\mathrm{n}=$ $22)$, and $N$. bairdi $(n=27)$ ).

To establish length/weight relationships, a number of specimens were weighed to nearest 1.0 g. Regressions of the form $w=a L^{b}$ (where $w=$ weight $(\mathrm{g}), \mathrm{L}=$ length $(\mathrm{cm}), a=$ slope and $b=$ intercept) were carried out on mean weights by sex, 
and for sexes combined for $C$. rupestris $(n=726)$, C. güentheri $(\mathrm{n}=842)$ and $M$. berglax $(\mathrm{n}=753)$ for both AFL (1 cm groups) and TL (3 cm groups) (Anon., 1985).

Scales were collected between the dorsal fins above the lateral line from $C$. rupestris and $M$. berglax for age determination. The age was determined using polarized light (Kosswig, MS 1979; Savvatimsky et al., 1977; Savvatimsky, 1994). Mean length-at-age was fitted to the following growth models:

Polynomial regression: $A F L=K \times a g e^{c}$,

von Bertalanffy: $A F L=L_{\infty} \times\left(1-K \times \exp \left(-t_{0} \times\right.\right.$ age $\left.)\right)$

and

Gompertz: $A F L=L_{\infty} \times\left(\exp \left(-K \times \exp \left(-t_{0} \times\right.\right.\right.$ age $\left.\left.)\right)\right)$

where $A F L=$ mean length $(\mathrm{cm})$,

$L_{\infty}=$ asymptotic standard length,

age $=$ age in years

and $\mathrm{K}, \mathrm{t}_{0}$ and $\mathrm{c}$ constants to be derived.

Least square estimation of parameters was carried out using the NLIN procedure of PC-SAS (Anon., 1985). An F-test was used to test if there was a significant improvement in the estimation of the regressions using a von Bertalanffy or Gompertz growth equation compared to a polynomial regression. For C. rupestris age material consisted of 178 males and 185 females sampled in 1988. For M. berglax, 164 males and 188 females sampled in 1988, 1989 and 1992.

Stomachs were examined from C. rupestris, C. güentheri, C. brevibarbis and $M$. berglax to determine diets (Table 2). Only fish showing no signs of regurgitation were sampled. Stomachs, or whole fish, were frozen and stored at $<-18^{\circ} \mathrm{C}$ prior to examination. The stomach contents were identified to lowest possible taxon in the laboratory. Each food category was weighed to the nearest $0.1 \mathrm{~g}$ wet weight. Diet results are given as frequency of occurrence, i.e. the number of stomachs in which a prey item occurred, expressed as a percentage of the total number of stomachs investigated containing food items, and weight percentage, i.e. the total weight of each prey item or prey group in the sample converted to a percentage of the weight of total stomach contents in the sample.

The gonads of $C$. rupestris ( $n=555$, covering the period June-December) and $C$. güentheri ( $\mathrm{n}=$ 293, sampled in August) were weighed to $0.1 \mathrm{~g}$ in order to investigate reproductive biology. Further, the reproductive status of 7816 specimens of $C$. rupestris caught in the period April-December were examined visually in connection with routine sexing during the surveys.
Near-bottom temperatures were measured, by $0.1^{\circ} \mathrm{C}$, as close as possible to the bottom either by CTD or XBT at 815 of the 945 trawl stations.

\section{Results and Discussion}

Coryphaenoides rupestris Gunnerus, 1765 (Roundnose grenadier, Rock grenadier)

Coryphaenoides rupestris is widely distributed in the North Atlantic (Marshall and Iwamoto, 1973), and is the most abundant macrourid in West Greenland waters (the survey had up to 7302 specimens in one haul). Coryphaenoides rupestris was found from south of Cape Farewell $\left(59^{\circ} 27^{\prime} \mathrm{N}\right)$ to $67^{\circ} 15^{\prime} \mathrm{N}$ (a single specimen was caught at $70^{\circ} 44^{\prime} \mathrm{N}$ ) at depths between $223 \mathrm{~m}$ and $1497 \mathrm{~m}$ and temperatures ranging from 1.1 to $5.4^{\circ} \mathrm{C}$. The species has been reported to occur at depths down to 2 200 m (Iwamoto, 1990), and in West Greenland it was very likely occurring at depths beyond 1497 $\mathrm{m}$; the maximum depth covered in these surveys. Cory-phaenoides rupestris was mainly found in waters from approximately $63^{\circ} 03^{\prime} \mathrm{N}$ to $64^{\circ} 30^{\prime} \mathrm{N}$ (Fig. 2 ), at depths $>800 \mathrm{~m}$ and temperatures between 3.2 and $4.0^{\circ} \mathrm{C}$, in agreement with Parsons (1976) who gave an optimum temperature range between 3.0 and $4.5^{\circ} \mathrm{C}$ for the northern part of the Davis Strait. In 1987, when the surveys covered the area between Cape Farewell and 69 $57^{\prime} \mathrm{N}$ (Div. 1A-1F) at depths between 34 and $998 \mathrm{~m}, 0.2 \%$ of the abundance was found at depths $<400 \mathrm{~m}$, and $1 \%$ of the abundance was found outside Div. $1 \mathrm{C}$ and 1D, the bulk in Div. 1B. Since 1987 C. rupestris has been observed outside Div. $1 \mathrm{C}$ and $1 \mathrm{D}$ only very sporadically. In Div. 1C and $1 \mathrm{D}$ at depths $>400 \mathrm{~m}$, abundance fluctuated significantly between years from 7946 specimens per km² in 1987 to 399 specimens per $\mathrm{km}^{2}$ in 1994 (Table 3), despite no commercial fishery directed to $C$. rupestris had been taking place during this period. There were also observed great variations in abundance within the year. In 1990 the abundance increased from 436 specimens per $\mathrm{km}^{2}$ in June to 1865 specimens per $\mathrm{km}^{2}$ in August/September, and in 1992 the abundance decreased from 5583 specimens per km² in August to 507 specimens per $\mathrm{km}^{2}$ in November/December, indicating annual migrations in and out of the survey area. Generally the abundance increased with depth to 1 000-1 $200 \mathrm{~m}$, however, the depth with greatest abundance varied between years and the time of the year, which was also observed by Chumakov and Savvatimsky (MS 1987). When comparing Div. $1 \mathrm{C}$ and $1 \mathrm{D}$ at the same depth, there was a tendency towards a higher abundance in Div. 1D, except at 1 000-1200 m depth. This depth stratum was, however, small in Div. 1C and located just north of the border between Div. 1D and 1C. Of the 7 816 specimens examined during the surveys, $56 \%$ were male. 
TABLE 2. Stomach analyses by species giving number of stomachs sampled (N), including empty stomachs but excluding fish with regurgitated stomachs, number of stomachs containing food items ( $n$ ), and sampling period, in relation to fish length range ( $A F L, c m$ ) of the specimens examined, sampling area and depth.

\begin{tabular}{|c|c|c|c|c|c|c|}
\hline Species & $\begin{array}{l}\text { Length range } \\
(\mathrm{AFL} \text { in } \mathrm{cm})\end{array}$ & Area & $\begin{array}{l}\text { Depth range } \\
(\mathrm{m})\end{array}$ & Date & $N$ & $n$ \\
\hline C. rupestris & $4.5-20.0$ & $63^{\circ} 04^{\prime}-65^{\circ} 56^{\prime} \mathrm{N}$ & $426-1482$ & $\begin{array}{r}9 \text { Jun - } 20 \text { Jun } 1990 \\
28 \text { Aug - } 6 \text { Sep } 1990 \\
07 \text { Aug - } 13 \text { Aug } 1991 \\
03 \text { Dec-07 Dec } 1992\end{array}$ & $\begin{array}{r}85 \\
156 \\
121 \\
45\end{array}$ & $\begin{array}{r}75 \\
113 \\
103 \\
41\end{array}$ \\
\hline C. güentheri & $3.0-13.0$ & $63^{\circ} 19^{\prime}-63^{\circ} 57^{\prime} \mathrm{N}$ & $1083-1424$ & $\begin{array}{l}29 \text { Aug - 30Aug } 1990 \\
05 \text { Aug - } 12 \text { Aug } 1991\end{array}$ & $\begin{array}{r}65 \\
265\end{array}$ & $\begin{array}{r}35 \\
162\end{array}$ \\
\hline C. brevibarbis & $4.0-6.0$ & $63^{\circ} 11^{\prime} \mathrm{N}$ & 1490 & 06 Aug 1991 & 6 & 5 \\
\hline M. berglax & $3.0-38.0$ & $63^{\circ} 04^{\prime}-69^{\circ} 45^{\prime} \mathrm{N}$ & $351-1430$ & $\begin{array}{l}09 \text { Jun - } 20 \text { Jun } 1990 \\
28 \text { Aug - } 12 \text { Sep } 1990 \\
07 \text { Aug - 25 Aug } 1991 \\
13 \text { Aug - 24 Aug } 1992 \\
30 \text { Nov-07 Dec } 1992\end{array}$ & $\begin{array}{r}110 \\
49 \\
83 \\
204 \\
87\end{array}$ & $\begin{array}{r}77 \\
45 \\
63 \\
179 \\
56\end{array}$ \\
\hline
\end{tabular}

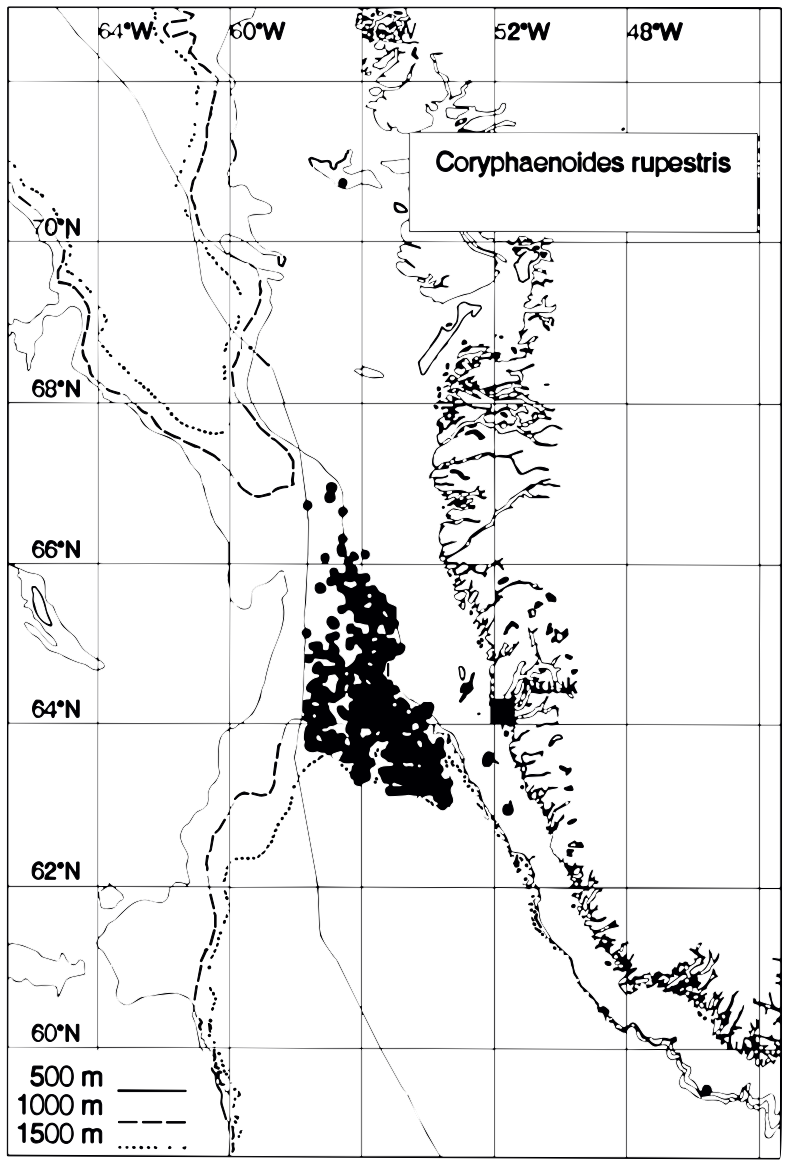

Fig. 2. Distribution of hauls in which $C$. rupestris was caught in the surveys of 1987-94.
Fish length ranged from $1.0 \mathrm{~cm}$ to $19.5 \mathrm{~cm}$ and $22.5 \mathrm{~cm}$ AFL for males and females, respectively. However, length range and length distribution varied significantly between surveys, but generally most $C$. rupestris were between 4 and $14 \mathrm{~cm} \mathrm{AFL}$ (Fig. 3).

The AFL and TL were highly correlated for both males and females and for sexes combined $(P<0.01)$ (Table 4). Analysis of covariance indicated that the regression coefficients differed significantly between males and females $(P<0.01)$. Atkinson (1981) and Magnússon (MS 1987) also found a significant difference in the AFL/TL relationship between the sexes at Canada and Iceland, respectively. They, furthermore, found a ratio of approximately 0.215 and 0.212 between the two types of length measurements, respectively, which is close to the ratio of approximately 0.230 found in the present investigations.

The relationship between both $A F L$ and $T L$ and weight was highly significant for each sex and for sexes combined $(P<0.01)$ (Table 5$)$. The weight-atlength was higher than observed by Atkinson (1989) in 1986-87 and Savvatimsky and Atkinson (1993) in the period 1968-80. They stated, however, that weight-at-length varies from time to time in the northern part of the Davis Strait, but the reason is unknown.

Fish age ranged from 4 to 20 years for both males and females. A great range in lengths within 
JØRGENSEN: Distribution and Biology of Grenadiers

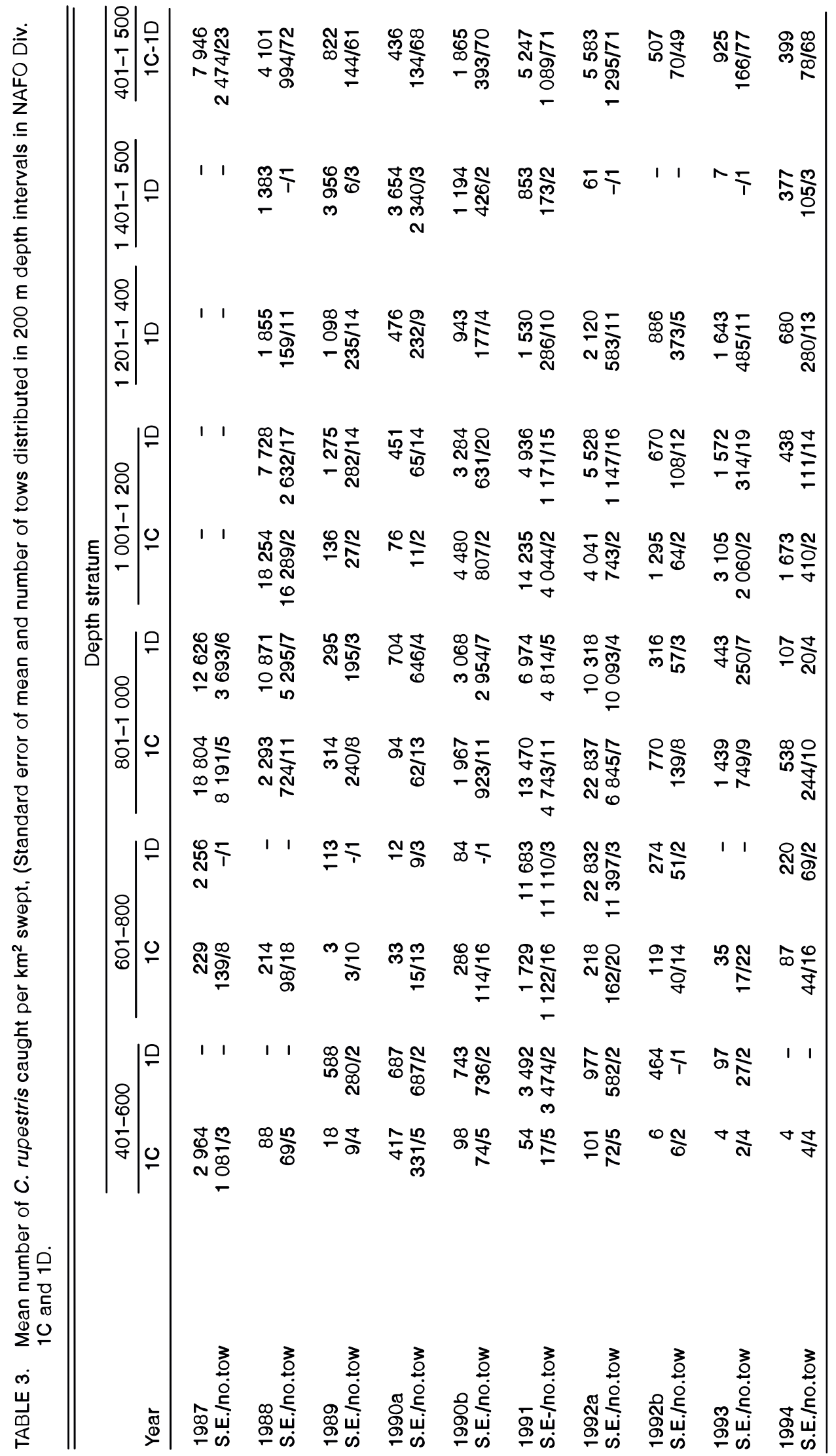



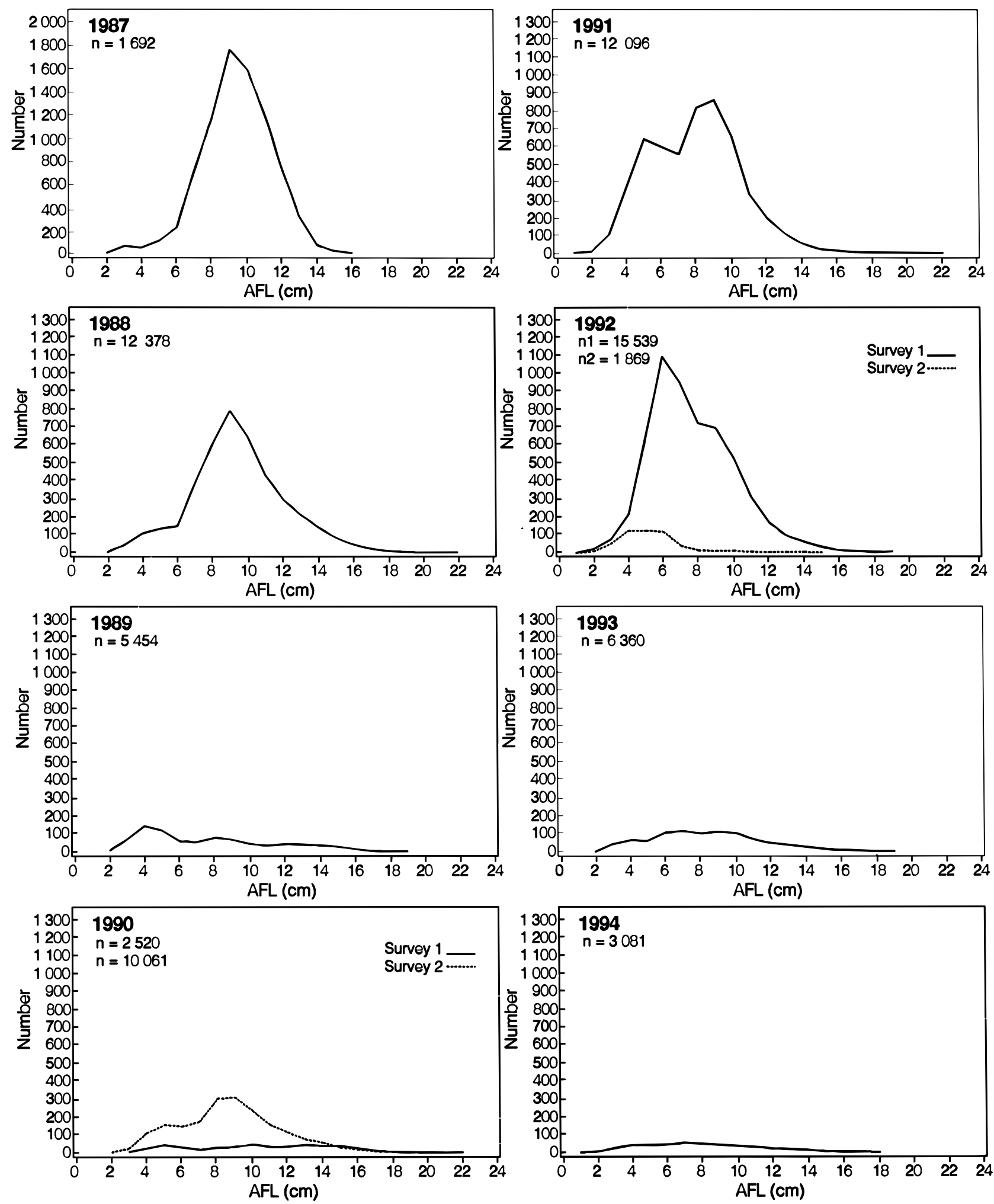

Fig. 3. Length distribution (AFL, 1-cm groups) of $C$. rupestris collected in numbers $(n)$ per km² swept in Div. $1 C+1 D$ at depths $>400 \mathrm{~m}$ in the period 1987-94 
TABLE 4. Relationship between total length $(T L)(\mathrm{cm})$ and preanal fin length $(A F L)(\mathrm{cm})$.

\begin{tabular}{|c|c|c|c|c|c|}
\hline \multirow[b]{2}{*}{ Species } & \multirow[b]{2}{*}{$\mathrm{n}$} & \multirow[b]{2}{*}{ Expression } & \multirow[b]{2}{*}{$r^{2}$} & \multicolumn{2}{|c|}{ Length range } \\
\hline & & & & AFL & $\mathrm{TL}$ \\
\hline \multicolumn{6}{|l|}{ C. rupestris } \\
\hline Sexes combined & 658 & $\mathrm{TL}=-4.126+\mathrm{AFL} 4.672$ & 0.92 & $4.5-19.5$ & $17-85$ \\
\hline Males & 363 & $T L=-5.786+A F L 4.853$ & 0.92 & $5.0-18.0$ & $19-80$ \\
\hline Females & 295 & $T L=-2.973+A F L 4.538$ & 0.93 & $4.5-19.5$ & $17-85$ \\
\hline \multicolumn{6}{|l|}{ C. güentheri } \\
\hline Sexes combined & 752 & $T L=2.378+A F L 3.246$ & 0.93 & $3.0-13.0$ & $10-43$ \\
\hline \multicolumn{6}{|l|}{ C. brevibarbis } \\
\hline Sexes combined & 24 & $T L=0.075+A F L 3.511$ & 0.87 & $3.5-8.0$ & $10-26$ \\
\hline \multicolumn{6}{|l|}{ M. berglax } \\
\hline Sexes combined & 498 & $T L=5.744+A F L 2.273$ & 0.98 & $3.0-38.0$ & $10-89$ \\
\hline \multicolumn{6}{|l|}{ T. murrayi } \\
\hline Sexes combined & 22 & $\mathrm{TL}=3.985+\mathrm{AFL} 2.238$ & 0.98 & $7.0-23.0$ & $19-55$ \\
\hline \multicolumn{6}{|l|}{ N. bairdi } \\
\hline Sexes combined & 27 & $\mathrm{TL}=13.967+\mathrm{AFL} 2.351$ & 0.57 & $5.0-9.5$ & $22-38$ \\
\hline
\end{tabular}

TABLE 5. Relationship between preanal fin length (AFL $\mathrm{cm}$ ) and weight $(\mathrm{g})$; and total length (TL cm), and weight for $C$. rupestris, $C$. güentheri and $M$. berglax.

\begin{tabular}{|c|c|c|c|c|}
\hline \multirow[b]{2}{*}{ Species } & \multirow[b]{2}{*}{$\mathrm{n}$} & \multicolumn{3}{|c|}{ Regression } \\
\hline & & Slope & Intercept (In) & $r^{2}$ \\
\hline \multicolumn{5}{|l|}{ C. rupestris } \\
\hline Male AFL & 332 & 2.9530 & -1.4042 & 0.999 \\
\hline Female AFL & 318 & 2.8638 & -1.1872 & 0.999 \\
\hline Sexes comb. AFL ${ }^{a}$ & 726 & 2.6869 & -0.7384 & 0.988 \\
\hline Male TL & 244 & 2.5610 & -4.1657 & 0.997 \\
\hline Female TL & 194 & 2.6102 & -4.2964 & 0.989 \\
\hline Sexes comb. TL ${ }^{a}$ & 513 & 2.5126 & -3.9512 & 0.996 \\
\hline \multicolumn{5}{|l|}{ C. güentheri } \\
\hline Males AFL & 406 & 2.6566 & -1.1890 & 0.993 \\
\hline Females AFL & 436 & 2.7552 & -1.3842 & 0.997 \\
\hline Sexes comb. AFL & 842 & 2.7046 & -1.2819 & 0.997 \\
\hline Males TL & 371 & 2.6073 & -4.3310 & 0.984 \\
\hline Females TL & 385 & 2.6772 & -4.5376 & 0.986 \\
\hline Sexes comb. TL & 756 & 2.6574 & -4.4756 & 0.986 \\
\hline \multicolumn{5}{|l|}{ M. berglax } \\
\hline Males AFL & 323 & 2.6570 & -1.3544 & 0.996 \\
\hline Females AFL & 430 & 2.7449 & -1.5359 & 0.997 \\
\hline Sexes comb. AFL & 753 & 2.7258 & -1.4818 & 0.997 \\
\hline Males TL & 224 & 2.9571 & -5.0742 & 0.998 \\
\hline Females TL & 283 & 3.1009 & -5.4612 & 0.992 \\
\hline Sexes comb. TL & 507 & 3.0987 & -5.4707 & 0.996 \\
\hline
\end{tabular}

a Including unsexed individuals. 
each age group was observed as is seen for several other slow growing deep water species (Table $6)$. Growth curves were calculated according to the formulas: $A F L=2.516 \times$ age $^{0.678}$ and $A F L=2.219$ $\times$ age $^{0.755}$ (Polynomial regression), $A F L=29.250 \times$ $(1-0.965 \times \exp (-0.050 \times$ age $))$ and $A F L=51.142 \times$ $(1-0.969 \times \exp (-0.025 \times$ age $))($ von Bertalanffy) and $A F L=22.810 \times(\exp (-2.051 \times \exp (-0.117 \times$ age $)))$ and $A F L=28.828 \times(\exp (-2.196 \times \exp (-0.097 \times$ age))) (Gompertz) for males and females, respectively. An F-test comparing the Polynomial regression with the von Bertalanffy and Gompertz growth models, showed that the von Bertalanffy and Gompertz growth models fitted data significantly better $(P<0.05)$ than the Polynomial regression for males, while no significant improvement in the data fit to the model was obtained by going from the simple Polynomial regression model to the more complex von Bertalanffy or Gompertz models, for females. The Gompertz model fitted mean size-at-age data a little better compared to the von Bertalanffy model in terms of slightly smaller residuals in the non-linear least square procedure (Anon., 1985). Mean size-at-age calculated according to the Gompertz model differed considerably for males and females with the largest size being observed for females (Fig 4). This difference in size-at-age between males and females was also observed at Newfoundland (Savvatimsky, 1972) and at Iceland, although size-at-age at West Greenland was larger in most age groups than at Iceland (data from Magnússon, MS 1987, fitted to a Gompertz growth curve) (Fig. 4). By using the conversion factor previously obtained (Table 4 ), the relationship $T L=$ $103.000 \times(\exp (-2.328 \times \exp (-0.125 \times$ age $)))$ and $T L=125.845 \times(\exp (-2.327 \times \exp (-0.101 \times$ age $)))$ were achieved for males and females, respectively. Size-at-age data for sexes combined from Kosswig (MS 1980) fitted to a Gompertz growth curve corresponded well with the size-at-age estimated in this study, while the size at age at Newfoundland also fitted to a Gompertz growth curve was somewhat higher than at West Greenland (Savvatimsky, 1972) (Fig. 5). Very little work has been done on intercalibration between age readers from different laboratories, and the differences in mean size-atage observed between different investigations, need not necessarily be due to differences in growth, but can be caused by differences in the interpretation of growth zones especially in the central part of the scales and for older fish. Gordon (MS 1978) found size-at-age for sexes combined based on otoliths at West Scotland in the same range as seen at West Greenland and Savvatimsky et al. (1977) showed that there was a good agreement between age readings based on scales and otoliths sampled from the same fish. Atkinson et al. (1982) found, however, great discrepancies in the results of the two methods. These discrepancies need to be resolved, and both age reading methods still have to be properly validated.

A total of 407 stomachs were sampled at different times of the year (Table 2) of which $18.4 \%$ were empty. The percentage of empty stomachs varied from $9 \%$ in December to $22 \%$ in August/September. Overall, 38 different food items or groups of food items were identified in the stomachs, representing five major animal classes or super-classes; Polychaeta, Cephalopoda, Crustacea, Echinoidea and Pisces (Table 7). The most important prey group throughout the year, both in terms of weight and

TABLE 6. Mean preanal fin length (AFL $\mathrm{cm}$ )-at-age; minimum and maximum length-at-age, number of observations (n) and Standard Error of mean (S.E.) by sex for C. rupestris.

\begin{tabular}{|c|c|c|c|c|c|c|c|c|c|c|}
\hline \multirow[b]{2}{*}{ Age } & \multicolumn{5}{|c|}{ Males } & \multicolumn{5}{|c|}{ Females } \\
\hline & Length & Min. & Max. & $n$ & S. E. & Length & Min. & Max. & $n$ & S.E. \\
\hline 4 & 6.33 & 6.0 & 7.0 & 6 & .167 & 6.75 & 6.5 & 7.0 & 2 & .250 \\
\hline 5 & 7.00 & 6.5 & 7.5 & 2 & .500 & 6.92 & 6.5 & 7.5 & 6 & .154 \\
\hline 6 & 8.50 & 7.5 & 10.5 & 14 & .234 & 9.08 & 8.0 & 9.5 & 6 & .271 \\
\hline 7 & 9.50 & 8.5 & 12.5 & 19 & .276 & 9.44 & 7.5 & 10.5 & 17 & .210 \\
\hline 8 & 10.09 & 8.5 & 11.5 & 16 & .234 & 10.50 & 8.5 & 13.5 & 15 & .384 \\
\hline 9 & 11.31 & 10.0 & 12.5 & 13 & .208 & 11.58 & 10.5 & 14.0 & 13 & .329 \\
\hline 10 & 11.80 & 10.0 & 13.0 & 10 & .271 & 12.41 & 10.0 & 15.5 & 23 & .279 \\
\hline 11 & 13.08 & 11.0 & 15.5 & 12 & .353 & 13.32 & 11.0 & 16.5 & 19 & .377 \\
\hline 12 & 13.34 & 11.5 & 16.5 & 19 & .289 & 14.13 & 12.0 & 17.0 & 20 & .278 \\
\hline 13 & 14.98 & 13.5 & 16.5 & 20 & .222 & 15.48 & 13.0 & 17.0 & 20 & .265 \\
\hline 14 & 15.39 & 13.5 & 17.5 & 19 & .197 & 16.56 & 15.0 & 18.5 & 18 & .235 \\
\hline 15 & 16.33 & 15.5 & 17.5 & 3 & .601 & 18.14 & 17.0 & 19.5 & 7 & .322 \\
\hline 16 & 16.25 & 15.0 & 17.5 & 6 & .382 & 18.25 & 16.0 & 22.0 & 14 & .441 \\
\hline 17 & 16.87 & 16.5 & 18.0 & 8 & .183 & 18.50 & 18.0 & 19.0 & 2 & .500 \\
\hline 18 & 18.25 & 17.5 & 19.5 & 6 & .335 & - & - & - & - & - \\
\hline 19 & 18.50 & 17.5 & 19.5 & 4 & .456 & 21.00 & 20.5 & 21.5 & 2 & .500 \\
\hline 20 & 18.50 & 18.5 & 18.5 & 1 & - & 20.50 & 20.5 & 20.5 & 1 & - \\
\hline
\end{tabular}




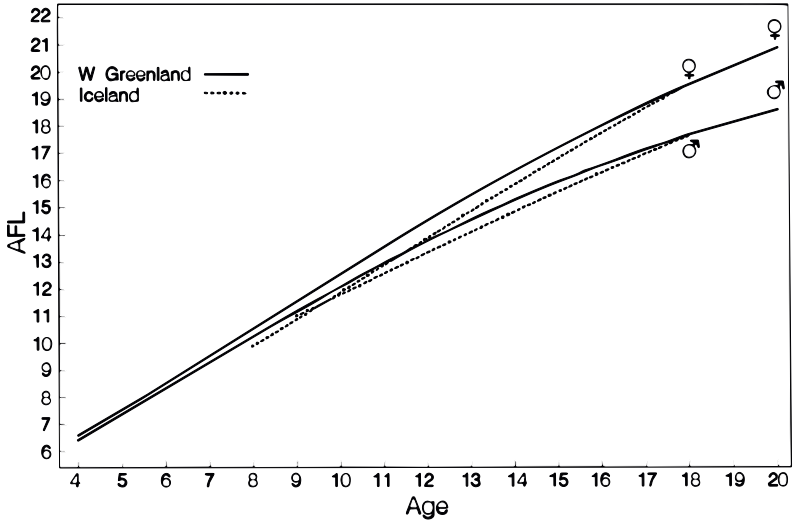

Fig. 4. Age-length relationship (AFL $\mathrm{cm}$ ) for $C$. rupestris at West Greenland and Iceland (Magnússon, MS 1987) fitted to a Gompertz growth curve.

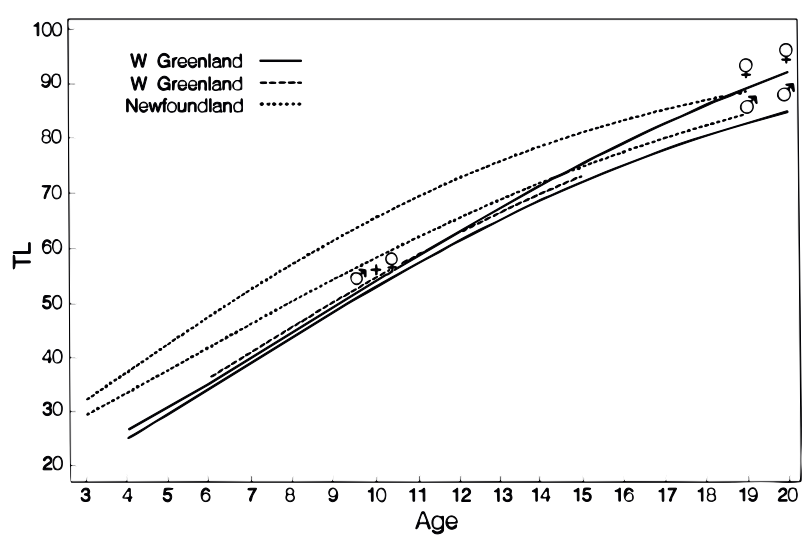

Fig. 5. Age-length relationship ( $T L \mathrm{~cm}$ ) for $C$. rupestris at West Greenland in 1979 (sexes combined) (Kosswig, MS 1980), from the present studies and Newfoundland (Savvatimsky, 1972) fitted to a Gompertz growth curve.

frequency of occurrence was Crustacea. Their importance increased during the year from $23 \%$ of the food by weight in June to $78 \%$ in winter, corresponding to $73 \%$ and $100 \%$ frequency of occurrence, respectively. The most important Crustaceans (by weight) were Natantia, Copepoda and Euphausiacea. Overall, Pisces and Cephalopoda were the second and third most important groups by weight, contributing $18 \%$ and $16 \%$, respectively. While the weight percentage of fish was relatively stable throughout the year, the weight percentage of Cephalopoda fell from $22 \%$ in June to $1 \%$ in December. Polychaeta were found in $25 \%$ of the stomachs, but contributed only $2 \%$ by weight. The total number of fish species encountered was rather low, however, each specimen contributed a large proportion by weight. The frequency of occurrence of
Pisces was relatively high, due to the fact that a number of stomachs contained fish scales, which might have been consumed in the trawl during trawling and hauling.

The importance of Crustacea as food (by weight) (with the exception of Natantia) declined with increasing fish size, while the importance of Pisces and Cephalopoda increased dramatically with size, both in weight and frequency of occurrence (Table 8 ).

Gushchin and Podrazhanskaya (1984) found a similar overall distribution in the food composition at West Greenland. The only significant difference observed in this study was that Amphipoda and Mysidacea were more dominant, $28 \%$ and $18 \%$ by weight, respectively. Gushchin and Podrazhanskaya (1984) also observed the increase in the importance of Pisces and Cephalopoda, and a decrease in the importance of Crustacea as food, with increasing fish size.

The results reported by Konstantinov and Podrazhanskaya (1972) from the central part of the Davis Strait are, however, rather different when compared to these studies, in that they report a high occurrence of Amphipoda and Natantia, 60\% and $54 \%$, respectively. The only similarity between their results and those presented in this study is in the high occurrence of Calanus (45\%). The large differences between the investigations, especially in the occurrence of Amphipoda, probably reflects variations in the abundance of Amphipoda rather than changes in $C$. rupestris preference for this prey.

The composition of the food indicates that $C$. rupestris is a benthopelagic feeder, foraging to a large extent in the water column. This conclusion is supported by a number of observations of pelagic behaviour both at West Greenland, where as many as $390 \mathrm{~kg}$ were taken in one hour of pelagic trawling (Jørgensen and Akimoto, MS 1991), as well as other places in the North Atlantic (Haedrich, 1974; Savvatimsky, 1985).

There was no difference in gonad weights at different times of the year for 252 female and 303 male gonads sampled in the period June-December, but a tendency towards an increase in gonad weight by size was observed. In total 7 females between 14.5 and $23 \mathrm{~cm}$ AFL had gonads with weights above $10 \mathrm{~g}$ (maximum of $31 \mathrm{~g}$ ), however, eggs were not visible and the gonads were immature. Gonad weights of $1.0 \mathrm{~g}$ or above were observed in 155 females, of which the smallest was $7.5 \mathrm{~cm}$ AFL. Only 3 males, ranging between 15-20 $\mathrm{cm} \mathrm{AFL}$, had gonads with weights above $5 \mathrm{~g}$, while 21 males, of which the smallest was $11.5 \mathrm{~cm} \mathrm{AFL,}$ had gonads with weights of and above $1.0 \mathrm{~g}$. None 
TABLE 7. Food of $C$. rupestris expressed as weight percentage and frequency of occurrence at different times of the year.

\begin{tabular}{|c|c|c|c|c|c|c|c|c|}
\hline \multirow[b]{2}{*}{ Food item } & \multicolumn{4}{|c|}{ Weight percentage } & \multicolumn{4}{|c|}{ Frequency of Occurrence } \\
\hline & Jun & Aug/Sep & Nov/Dec & All & Jun & Aug/Sep & Nov/Dec & All \\
\hline Polychaeta & 5.56 & 0.93 & 2.67 & 1.92 & 38.67 & 17.59 & 39.02 & 25.00 \\
\hline Cephalopoda & 22.18 & 15.30 & 0.94 & 16.10 & 36.00 & 33.33 & 2.44 & 30.12 \\
\hline Crustacea (total) & 23.37 & 45.62 & 78.29 & 42.49 & 73.33 & 92.13 & 100.0 & 88.86 \\
\hline Ostracoda & & 0.01 & & 0.01 & & 0.46 & & 0.30 \\
\hline Copepoda & & 0.07 & & 0.05 & & 3.70 & & 2.41 \\
\hline Calanoida & 1.81 & 2.32 & 5.50 & 2.35 & 48.00 & 77.31 & 75.61 & 70.48 \\
\hline Mysidacea & 0.44 & 0.07 & & 0.14 & 2.67 & 1.85 & & 1.81 \\
\hline Gnathophausia & 0.69 & 1.12 & & 0.99 & 1.33 & 0.93 & & 0.90 \\
\hline Isopoda & & 0.02 & & 0.01 & & 0.46 & & 0.30 \\
\hline Hyperiidae unident. & 0.03 & 0.02 & 1.57 & 0.08 & 1.33 & 0.93 & 12.20 & 2.41 \\
\hline Parathemisto & 0.03 & 0.14 & & 0.11 & 1.33 & 2.31 & & 1.81 \\
\hline Gammaridea & & 0.11 & 0.47 & 0.11 & & 4.63 & 4.88 & 3.61 \\
\hline Euphausiacea & 2.19 & 12.43 & 6.45 & 10.16 & 2.67 & 41.20 & 48.78 & 33.43 \\
\hline Natantia (total) & 9.96 & 20.17 & 12.26 & 17.83 & 10.67 & 17.13 & 7.32 & 14.46 \\
\hline Pasiphaeidae & & 2.68 & & 2.04 & & 1.85 & & 1.20 \\
\hline Hoplophoridae & & 1.56 & & 1.19 & & 1.85 & & 1.20 \\
\hline Achanthephyra sp. & & 5.71 & & 4.35 & & 2.31 & & 1.51 \\
\hline Bythocaris sp. & & 0.28 & & 0.21 & & 0.46 & & 0.30 \\
\hline Pandalus sp. & & 0.28 & & 0.21 & & 0.46 & & 0.30 \\
\hline Pandalus borealis & 2.31 & 1.07 & & 1.28 & 1.33 & 0.46 & & 0.60 \\
\hline Natantia unident. & 7.65 & 8.59 & 12.26 & 8.55 & 9.33 & 10.65 & 7.32 & 9.94 \\
\hline Crustacea unident. & 8.22 & 9.14 & 52.04 & 10.65 & 42.67 & 33.80 & 92.68 & 43.07 \\
\hline Echinoidea & 0.03 & & & 0.01 & 1.33 & & & 0.30 \\
\hline Pisces (total) & 10.84 & 20.39 & 14.94 & 18.28 & 33.33 & 16.20 & 7.32 & 18.98 \\
\hline Bathylagus euryops & & 3.76 & & 2.86 & & 0.46 & & 0.30 \\
\hline Cyclothone microdon & & 0.18 & 14.47 & 0.71 & & 0.46 & & 0.60 \\
\hline Holtbyrnia anomala & & 1.63 & & 1.24 & & 0.46 & & 0.30 \\
\hline Macrouridae sp. & & 12.32 & & 9.39 & & 0.46 & & 0.30 \\
\hline Pisces sp. & 10.84 & 2.50 & 0.47 & 4.08 & 33.33 & 14.35 & 4.88 & 17.47 \\
\hline Unidt. organic mat. & 38.02 & 17.76 & 3.14 & 21.20 & 61.33 & 31.94 & 17.07 & 36.75 \\
\hline All & 100 & 100 & 100 & 100 & & & & \\
\hline Stomachs & 75 & 216 & 41 & 332 & 75 & 216 & 41 & 332 \\
\hline
\end{tabular}

of the gonads showed signs of maturation. Out of 7816 specimens, sampled in the period AprilDecember, which were examined visually, only one female, $21 \mathrm{~cm}$ AFL, sampled in September showed signs of maturation, having gonads with a weight of $105 \mathrm{~g}$ and containing eggs of $0.8 \mathrm{~mm}$. The remaining specimens had gonads with eggs not yet visible or small testes with no signs of maturation. No specimens seemed to be newly spent. There was thus no indication of spawning at West Greenland.

The existing information on $C$. rupestris spawning biology is scarce and is in many ways conflicting. According to Grigorev (1972), Savvatimsky (1982) and Gordon (MS 1978) C. rupestris spawns throughout the year, with a tendency towards a more intensive spawning in June-December, while Geistdoerfer (1979) showed that spawning takes place in spring. There has been very little evidence of spawning in the Northwest Atlantic. Savvatimsky
(1972) and Grigorev (1972) found no maturing or mature specimens at East Canada or West Greenland. Savvatimsky (1972) ascribed this to the lack of trawl hauls at relevant depths. He mentioned that maturing specimens were taken in a single haul at $1500 \mathrm{~m}$ off Labrador in October, and that post- and pre-spawning individuals were observed at depths between 850 and $1270 \mathrm{~m}$ in May off Nova Scotia. Further, Geistdoerfer (1979) also observed a few spent specimens taken at depths of 720-920 $\mathrm{m}$ in July-August off Labrador.

According to Zakharov and Monaku (1970) C. rupestris spawn at Southwest Iceland, and eggs and larvae drift by current to West Greenland and Baffin Island where they then settle. As fish grow larger they migrate back to Iceland to spawn. Savvatimsky (1982) agreed that the $C$. rupestris found in the Northwest Atlantic could have been spawned in Icelandic waters, but judging from the 
TABLE 8. Food of $C$. rupestris expressed as weight percentage and frequency of occurrence for fish below and above $10 \mathrm{~cm}$ preanal fish length, respectively.

\begin{tabular}{|c|c|c|c|c|}
\hline \multirow[b]{2}{*}{ Food item } & \multicolumn{2}{|c|}{ Weight percentage } & \multicolumn{2}{|c|}{ Frequency of occurrence } \\
\hline & $<10 \mathrm{~cm}$ & $>10 \mathrm{~cm}$ & $<10 \mathrm{~cm}$ & $>10 \mathrm{~cm}$ \\
\hline Polychaeta & 4.00 & 1.73 & 28.46 & 22.97 \\
\hline Cephalopoda & 0.53 & 17.49 & 5.69 & 44.50 \\
\hline Crustacea (total) & 73.82 & 39.70 & 91.06 & 87.56 \\
\hline Ostracoda & & 0.01 & & 0.48 \\
\hline Copepoda & 0.23 & 0.03 & 2.44 & 2.39 \\
\hline Calanoida & 12.98 & 1.40 & 80.49 & 64.59 \\
\hline Mysidacea & 1.06 & 0.06 & 3.25 & 0.96 \\
\hline Gnathophausia & & 1.08 & & 1.44 \\
\hline Isopoda & & 0.01 & & 0.48 \\
\hline Hyperiidae unident. & 0.45 & 0.05 & 3.25 & 1.91 \\
\hline Parathemisto & 0.08 & 0.11 & 0.81 & 2.39 \\
\hline Gammaridea & 0.30 & 0.09 & 2.44 & 4.31 \\
\hline Euphausiacea & 14.04 & 9.82 & 23.58 & 39.23 \\
\hline Natantia (total) & 7.55 & 18.76 & 4.07 & 20.57 \\
\hline Pasiphaeidae & & 2.23 & & 1.91 \\
\hline Hoplophoridae & & 1.30 & & 1.91 \\
\hline Achanthephyra sp. & & 4.74 & & 2.39 \\
\hline Bythocaris sp. & & 0.23 & & 0.48 \\
\hline Pandalus sp. & 2.57 & & 0.81 & \\
\hline Pandalus borealis & & 1.39 & & 0.96 \\
\hline Natantia unident. & 4.98 & 8.87 & 3.25 & 13.88 \\
\hline Crustacea unident. & 37.13 & 8.28 & 47.15 & 40.67 \\
\hline Echinoidea & & 0.01 & & 0.48 \\
\hline Pisces (total) & 0.60 & 19.86 & 6.50 & 26.32 \\
\hline Bathylagus euryops & & 3.12 & & 0.48 \\
\hline Cyclothone microdon & & 0.77 & & 0.96 \\
\hline Holtbyrnia anomala & & 1.35 & & 0.48 \\
\hline Macrouridae sp. & & 10.23 & & 0.48 \\
\hline Pisces sp. & 0.60 & 4.39 & 6.50 & 23.92 \\
\hline Unidt. organic & 21.06 & 21.22 & 28.46 & 41.63 \\
\hline All & 100 & 100 & & \\
\hline Stomachs & 123 & 209 & 123 & 209 \\
\hline
\end{tabular}

morphology of the species, Savvatimsky (1982), Grigorev (1972) and Parsons (1976), concluded that it is a poor swimmer, not capable of migrating over long distances. They therefore discounted Zakharov and Monaku's (1970) theory, and concluded, based on among others the observations of small individuals (Grigorev, 1972) and larvae (Jensen, 1948), that C. rupestris spawn in the Northwest Atlantic at depths greater than $1000 \mathrm{~m}$. The finding of only immature fish, except one, in the present study, and the fact that the abundance seems to decrease beyond about $1100 \mathrm{~m}$, does not support this hypothesis. A number of fish species in West Greenland are recruited from spawning areas at Iceland indicating that $C$. rupestris in West Greenland might also be recruited from Icelandic waters. Duschenko (1985) also reached the conclusion, that the population in the Davis Strait is completely dependent on recruitment from outside. He considered the West Greenland population as an expatriate population, because of the lack of evidence for spawning migrations back to the Mid-Atlantic Ridge.

Coryphaenoides güentheri (Valliant, 1888). (Günther's grenadier)

Coryphaenoides güentheri is distributed in the Mediterranean, in the Eastern Atlantic, off Iceland and East Greenland at depths between 800 and 2 $800 \mathrm{~m}$ (Iwamoto, 1990). In our surveys, it was found south of $66^{\circ} 04^{\prime} \mathrm{N}$ at depths between 534 and 1497 $\mathrm{m}$ and at temperatures ranging from 3.0 to $4.3^{\circ} \mathrm{C}$, but it was most abundant at temperatures between 3.2 and $3.6^{\circ} \mathrm{C}$ (Fig. 6). The species has been observed at depths of $1956 \mathrm{~m}$ in the Davis Strait (Karrer, 1976). Coryphaenoides güentheri was common with as many as 190 specimens being caught in a single haul. The main distribution area was in Div. 1D at depths greater than $1000 \mathrm{~m}$ where $97.3 \%$ of the catches were made. In this area abundance varied from 39 specimens per km² in 1990 to 395 


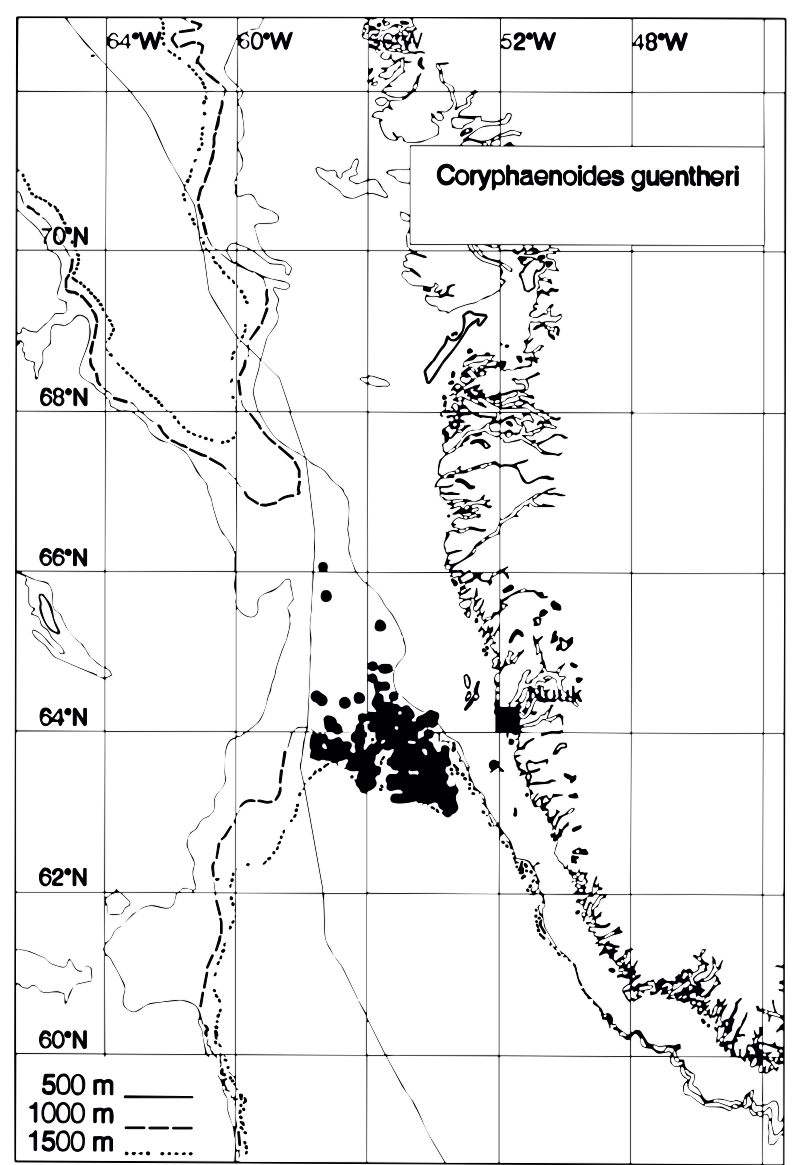

Fig. 6. Distribution of hauls in which C. güentheri was caught in the surveys of 1987-94.

specimens per $\mathrm{km}^{2}$ in 1991. In most surveys there was a tendency towards an increase in abundance by depth, but the opposite was observed in 1989 and 1992 (Table 9). Of the 162 examined specimens, $49 \%$ were male.

In the five surveys, from which length frequency data were available, fish length (AFL) ranged from 2.0 to $14.5 \mathrm{~cm}$. Most length distributions were dominated by one clear mode between 5 and $7 \mathrm{~cm}$ (Fig. 7).

The AFL and TL were highly correlated for each sex and for sexes combined $(P<0.01)$ (Table 4$)$. Analysis of covariance indicated that the regression coefficients did not differ significantly between sexes $(P=0.177)$ and the relationship between AFL and $T L$ was estimated at $T L=2.378+A F L \times 3.246$.

The relationship between both $A F L$ and $T L$ and weight was highly significant for each sex and for sexes combined $(P<0.01)$ (Table 5).
A total of 330 stomachs, of which $40 \%$ were empty, were investigated (Table 2). Overall, 22 different food items or groups of food items were identified, representing six major animal classes or super-classes; Polychaeta, Cephalopoda, Crustacea, Echinodermata, Mollusca and Pisces (Table 10). The most important prey was Crustacea, of which Gammaridea were dominant, both in terms of weight and percentage occurrence, closely followed by Polychaeta. Other important prey were Holothuroidae and Bivalvia, while Pisces and Cephalopoda only occurred sporadically. The composition of food items indicates that C. güentheri is a benthic feeder.

None of the gonads taken from 160 females and 133 males, ranging from 4 to $13 \mathrm{~cm}$ AFL sampled in August, showed any signs of maturation or being recently spent. There was, however, a tendency towards an increase in gonad weight by size for females. Hence, 12 females between 10 and $13 \mathrm{~cm}$ AFL had gonads with weights above $1.0 \mathrm{~g}$, the maximum weight being $1.7 \mathrm{~g}$ and two of the females sampled had barely visible eggs. One male, $11 \mathrm{~cm}$ $A F L$, had gonads with a weight of $0.2 \mathrm{~g}$. The rest had gonad weights equal to or less than $0.1 \mathrm{~g}$. Thus there were no indications of spawning at West Greenland, at least not during summer.

Coryphaenoides brevibarbis (Goode and Bean, 1896). (Shortbeard grenadier)

Coryphaenoides brevibarbis is distributed from the Bay of Biscay, west of Ireland to south of Iceland and east of southern Greenland, and in the Western Atlantic off the coast of North America (Geistdoerfer, 1986). The species is reported to be most common at depths between 1500 and 3200 $\mathrm{m}$ in the Western Atlantic (Marshall and Iwamoto, 1973). At West Greenland, it was found between $63^{\circ} 08^{\prime} \mathrm{N}$ and $64^{\circ} 26^{\prime} \mathrm{N}$ at depths from 984 to $1490 \mathrm{~m}$ and temperatures ranging from 2.9 to $3.5^{\circ} \mathrm{C}$ (Fig. 8). However, it has previously been observed to 1 $955 \mathrm{~m}$ in the Davis Strait (Karrer, 1976). A total of 57 specimens were caught, of which 17 were taken in a single haul at $1490 \mathrm{~m}$ at a temperature of $3.1^{\circ} \mathrm{C}$. Of the 12 specimens examined, $50 \%$ were male.

Fish length, in all surveys combined, ranged from 2.5 to $8.0 \mathrm{~cm} \mathrm{AFL,} \mathrm{with} \mathrm{most} \mathrm{being} \mathrm{between}$ 3.0 and $5.0 \mathrm{~cm}$ (Fig. 9). The relationship between $\mathrm{TL}$ and $\mathrm{AFL}$ was estimated to $\mathrm{TL}=0.075+\mathrm{AFL} \times$ 3.511 (Table 4).

Crustacea were found in all of the 6 stomachs examined, except one which was empty. Gammaridea was the most common group but Copepoda was found in a single stomach. 
TABLE 9. Mean number of $C$. güentheri caught per $\mathrm{km}^{2}$ swept, standard error (S.E.) of mean and number of tows distributed on $200 \mathrm{~m}$ depth intervals by year and cruise number in Div. 1D at depths $>1000 \mathrm{~m}$.

\begin{tabular}{|c|c|c|c|c|}
\hline \multirow[b]{2}{*}{ Year } & \multicolumn{4}{|c|}{ Depth stratum } \\
\hline & $1001-1200$ & $1201-1400$ & $1401-1500$ & $1001-1500$ \\
\hline 1988 & 136 & 194 & 286 & 163 \\
\hline S.E./no.tow & $33 / 17$ & $50 / 11$ & $-/ 1$ & $27 / 29$ \\
\hline 1989 & 171 & 136 & 77 & 146 \\
\hline S.E./no.tow & $33 / 14$ & $23 / 14$ & $30 / 3$ & $19 / 31$ \\
\hline $1990 a$ & 34 & 40 & 62 & 39 \\
\hline S.E./no.tow & $8 / 14$ & $22 / 9$ & $15 / 3$ & $9 / 26$ \\
\hline $1990 b$ & 124 & 148 & 212 & 134 \\
\hline S.E./no.tow & $19 / 20$ & $42 / 4$ & $134 / 2$ & $18 / 26$ \\
\hline 1991 & 345 & 406 & 720 & 395 \\
\hline S.E./no.tow & $72 / 15$ & $46 / 10$ & $204 / 2$ & $48 / 27$ \\
\hline $1992 a$ & 165 & 126 & 20 & 145 \\
\hline S.E./no.tow & $54 / 16$ & $45 / 11$ & $-/ 1$ & $36 / 28$ \\
\hline $1992 b$ & 271 & 186 & - & 246 \\
\hline S.E./no.tow & $105 / 12$ & $39 / 5$ & - & $75 / 17$ \\
\hline 1993 & 119 & 150 & 0 & 126 \\
\hline S.E./no.tow & $27 / 19$ & $23 / 11$ & $-/ 1$ & $19 / 31$ \\
\hline 1994 & 111 & 359 & 222 & 230 \\
\hline S.E./no.tow & $28 / 14$ & $85 / 13$ & $51 / 3$ & $44 / 30$ \\
\hline
\end{tabular}

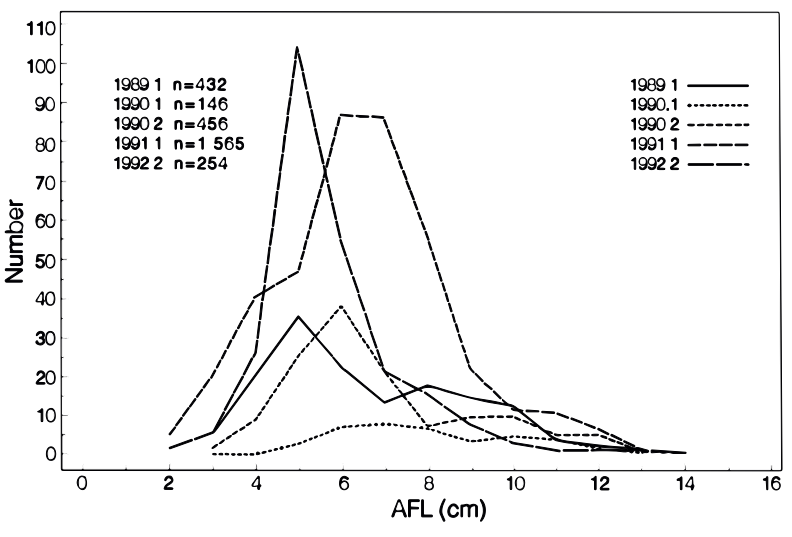

Fig. 7. Length distribution (AFL, 1-cm groups) of $C$. güentheri collected in numbers $(n)$ per $\mathrm{km}^{2}$ swept in Div. 1D at depths $>1000 \mathrm{~m}$ in the five surveys in the period 1989-92.

Polychaeta were found in four stomachs, indicating that the species is a benthic feeder.
Coryphaenoides carapinus Goode and Bean, 1883. (Carapine grenadier)

Coryphaenoides carapinus is distributed in the central/eastern North Atlantic from about $60^{\circ} \mathrm{N}$ to the Equator, along the Mid-Atlantic Ridge and between Cape Hatteras and Nova Scotia (Geistdoerfer, 1986). According to Marshall and Iwamoto (1973), most of the individuals recorded were sampled between 1400 and $2800 \mathrm{~m}$, however, it has been reported to occur as deep as $5610 \mathrm{~m}$. The species was not caught during these 1987-94 surveys, but a single specimen, $18.3 \mathrm{~cm} \mathrm{TL}$, taken at $62^{\circ} 58^{\prime} \mathrm{N}$ $57^{\circ} 42^{\prime} \mathrm{W}$, at a depth of $1950 \mathrm{~m}$ was reported by Karrer (1976) (Fig. 8).

Coryphaenoides armatus (Hector, 1875.

Coryphaenoides armatus is distributed worldwide at depths between 257 and $4700 \mathrm{~m}$, usually below $2000 \mathrm{~m}$ (Geistdoerfer, 1986). The species was not caught during the 1987-94 surveys, but Jensen (1948) reported two specimens, of which the largest was $36.1 \mathrm{~cm} \mathrm{TL}$, from the southern part of the Davis Strait at depths of 2600 and $3235 \mathrm{~m}$. 
TABLE 10. Food of $C$. güentheri expressed as weight percentage and frequency of occurrence.

\begin{tabular}{lrr}
\hline \hline Food item & Weight percentage & Frequency of occurrence \\
\hline Polychaeta & 24.82 & 75.13 \\
Cephalopoda & 0.16 & 0.51 \\
Crustacea (total) & 29.34 & 80.71 \\
Copepoda & 0.08 & 0.51 \\
Calanoida & 2.06 & 12.18 \\
Cumacea & 0.06 & 1.02 \\
Mysidacea & 2.14 & 6.60 \\
Isopoda & 0.08 & 0.51 \\
Hyperiidae unident. & 1.11 & 7.11 \\
Parathemisto & 0.16 & 1.02 \\
Gammaridea & 7.61 & 41.62 \\
Bythocaris sp. & 0.79 & 0.51 \\
Natantia unident. & 0.24 & 1.02 \\
Crustacea unident. & 14.91 & 68.02 \\
Holothuroidea & 11.66 & 3.55 \\
Ophiuroidea & 0.08 & 0.51 \\
Gastropoda & 0.16 & 1.02 \\
Bivalvia & 6.82 & 34.01 \\
Pisces sp. & 0.08 & 0.51 \\
Unidt. organic mat. & 26.88 & 62.94 \\
\hline All & 100 & \\
Stomachs & 197 & 197 \\
\hline
\end{tabular}

A further, two specimens, 16.1 and $18.5 \mathrm{~cm} \mathrm{TL}$, caught at a depth of $1955 \mathrm{~m}$ at $63^{\circ} \mathrm{N} 58^{\circ} \mathrm{W}$, were reported by Karrer (1976) (Fig. 8).

Macrourus berglax Lacépède, 1801. (Roughhead grenadier)

Macrourus berglax is widely distributed in temperate and arctic waters in the North Atlantic (Iwamoto, 1990). In these surveys it was found from $63^{\circ} 03^{\prime} \mathrm{N}$ to $72^{\circ} 47^{\prime} \mathrm{N}$ at depths between 280 and 1 $497 \mathrm{~m}$ and temperatures ranging from 0.1 to $4.6^{\circ} \mathrm{C}$, but with the highest abundance at temperatures between 3.0 and $4.2^{\circ} \mathrm{C}$ (Fig. 10). Macrourus berglax was common in the present study (up to 148 specimens in a single haul) and was caught in almost all hauls south of $67^{\circ} \mathrm{N}$ at depths $>400 \mathrm{~m}$. The species was mainly found between $63^{\circ} 03^{\prime} \mathrm{N}$ and $66^{\circ} 15^{\prime} \mathrm{N}$ (Div. 1CD) where the abundance fluctuated between 182 specimens per $\mathrm{km}^{2}$ in 1991 and 36 specimens per $\mathrm{km}^{2}$ in 1994. The highest abundance was found at depths from 600 to $1200 \mathrm{~m}$ (Table 11). Of the 7 078 specimens examined, $54 \%$ were male. Macrourus berglax has been taken down to 2000 $m$ offshore, but is probably found at even greater depths (Boje and Hareide, MS 1993). According to Wheeler (1969) it was caught as deep as $2740 \mathrm{~m}$. The species was, furthermore, found in almost all fjords at West Greenland up to $72^{\circ} \mathrm{N}$ (Jensen, 1948). The lack of offshore records between $63^{\circ} 03^{\prime} \mathrm{N}$ and Cape Farewell must be due to poor coverage of this area during the surveys, because it is frequently caught on long lines along the southwest coast (J. Boje, Greenland Institute of Natural Resources, Nuuk, Greenland, pers. com.).

Specimens in this study ranged from $0.5 \mathrm{~cm}$ to 27.0 and $42.5 \mathrm{~cm}$ AFL for males and females, respectively. The length distributions, differed, however, markedly between years and areas and within years in the same area (Fig. 11).

AFL and TL were highly correlated for both males and females and for sexes combined $(P<0.01)$. Analysis of covariance indicated that the regression coefficients did not differ significantly between males and females $(P=0.165)$, and the relationship between $T L$ and $A F L$ for sexes combined was estimated to $T L=5.744+A F L \times 2.273$ (Table 4). Several other authors have also found a linear correlation between AFL and TL and no significant difference between males and females (see Atkinson, 1991, for a review). Atkinson (1991) and Magnússon (MS 1987) estimated a ratio of 0.3783 and 0.3835 between AFL and TL in Canadian and Icelandic waters, respectively, which is close to the ratio 0.3752 found at West Greenland.

The relationship between both $A F L$ and $T L$ and weight was highly significant for both sexes and sexes combined $(P<0.01)$ (Table 5$)$. The weight-at- 


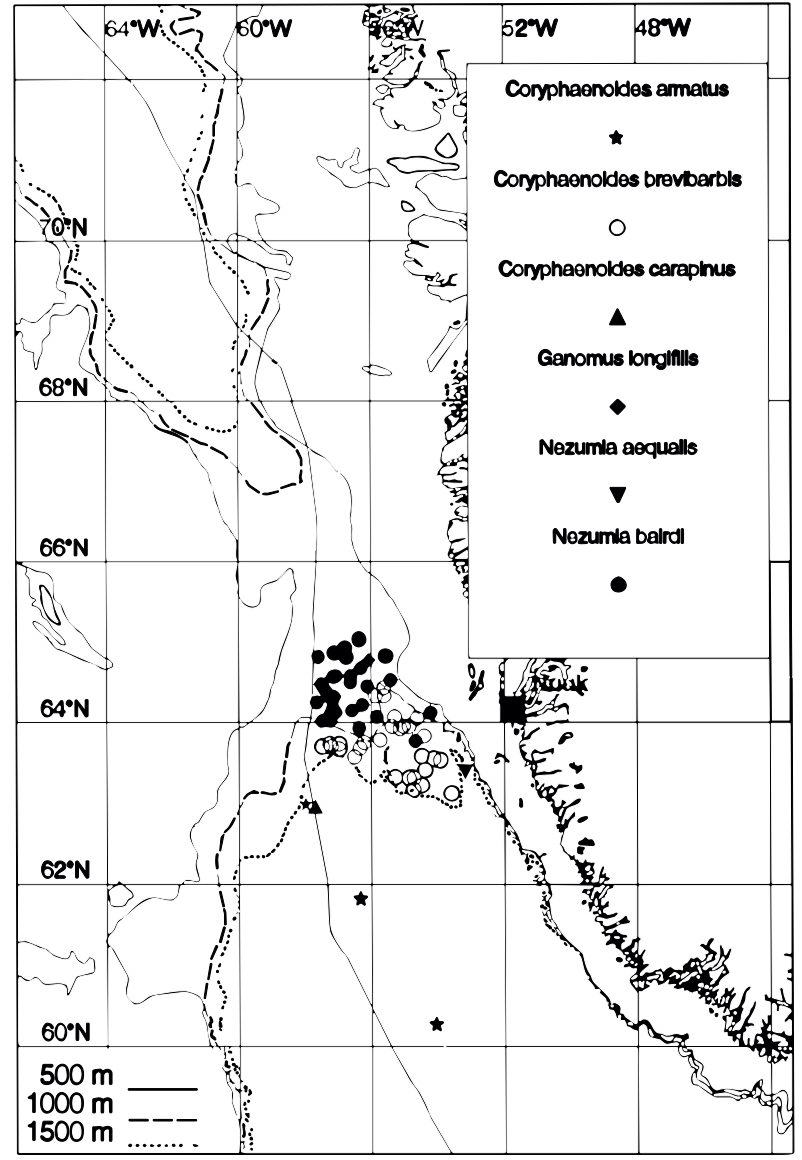

Fig. 8. Distribution of hauls in which $C$. brevibarbis, G. longifilis and N. bairdi were caught in the surveys of 1987-94. The position of observations of C. armatus, C. carapinus and $N$. aequalis given in Karrer (1976) and Jensen (1948) are also shown.

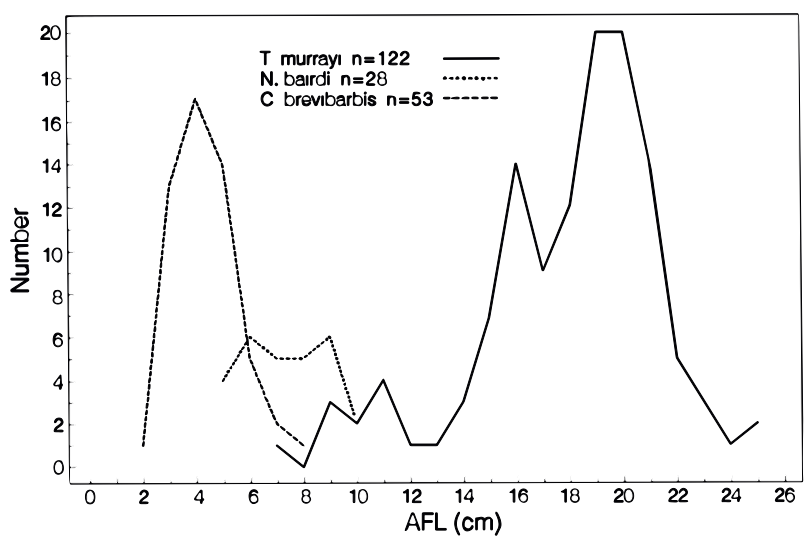

Fig. 9. Length distribution ( $A F L, 1-c m$ groups) of T. murrayi, N. bairdi and $C$. brevibarbis collected in numbers $(\mathrm{n})$ per $\mathrm{km}^{2}$ swept pooled for the period 1987-94.

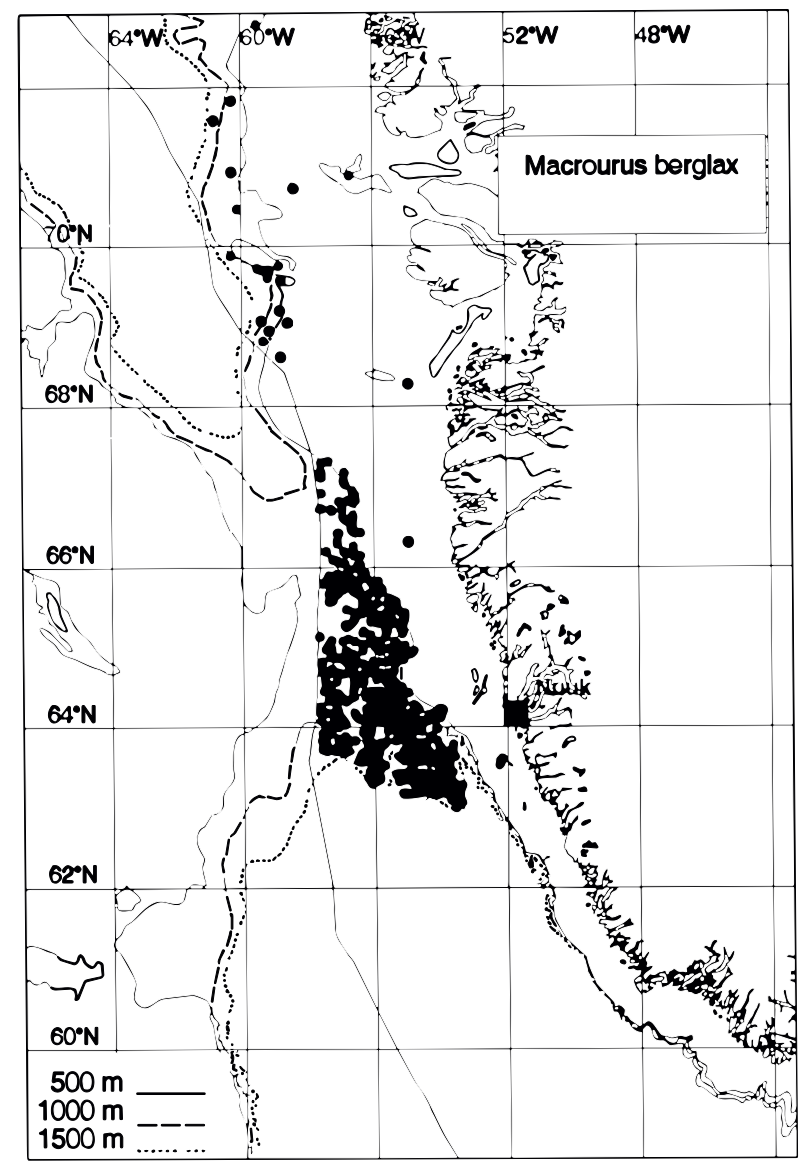

Fig. 10. Distribution of hauls in which M. berglax was caught in the surveys of 1987-94.

length was slightly higher compared to what was found by Savvatimsky (1989b and 1994) at East Canada in the period 1963-83 and in 1985, respectively, and by Magnússon (MS 1987) in Icelandic waters.

Scales were sampled in 1988, 1989 and 1992, but there was no significant difference in size-atage between years and data were pooled. Fish age ranged from 4 to 13 years and 3 to 19 years for males and females, respectively. As was the case with $C$. rupestris, a great variation in length within each age group was observed (Table 12). Growth curves were calculated according to the formulae: $\mathrm{AFL}=2.917 \times \mathrm{age}^{0.798}$ and $\mathrm{AFL}=2.579 \times \mathrm{age}^{0.875}$ (Polynomial regression), $A F L=28.556 \times(1-1.205 \times$ $\exp (-0.125 \times$ age $))$ and $A F L=108.421 \times(1-0.995 \times$ $\exp (-0.019 \times$ age $)$ ) (von Bertalanffy) and $A F L=$ $24.562 \times(\exp (-3.035 \times \exp (-0.244 \times$ age $)))$ and $A F L$ $=45.718 \times(\exp (-2.594 \times \exp (-0.111 \times$ age $)))$ (Gompertz) for males and females, respectively. An F-test comparing the Polynomial regression with the 


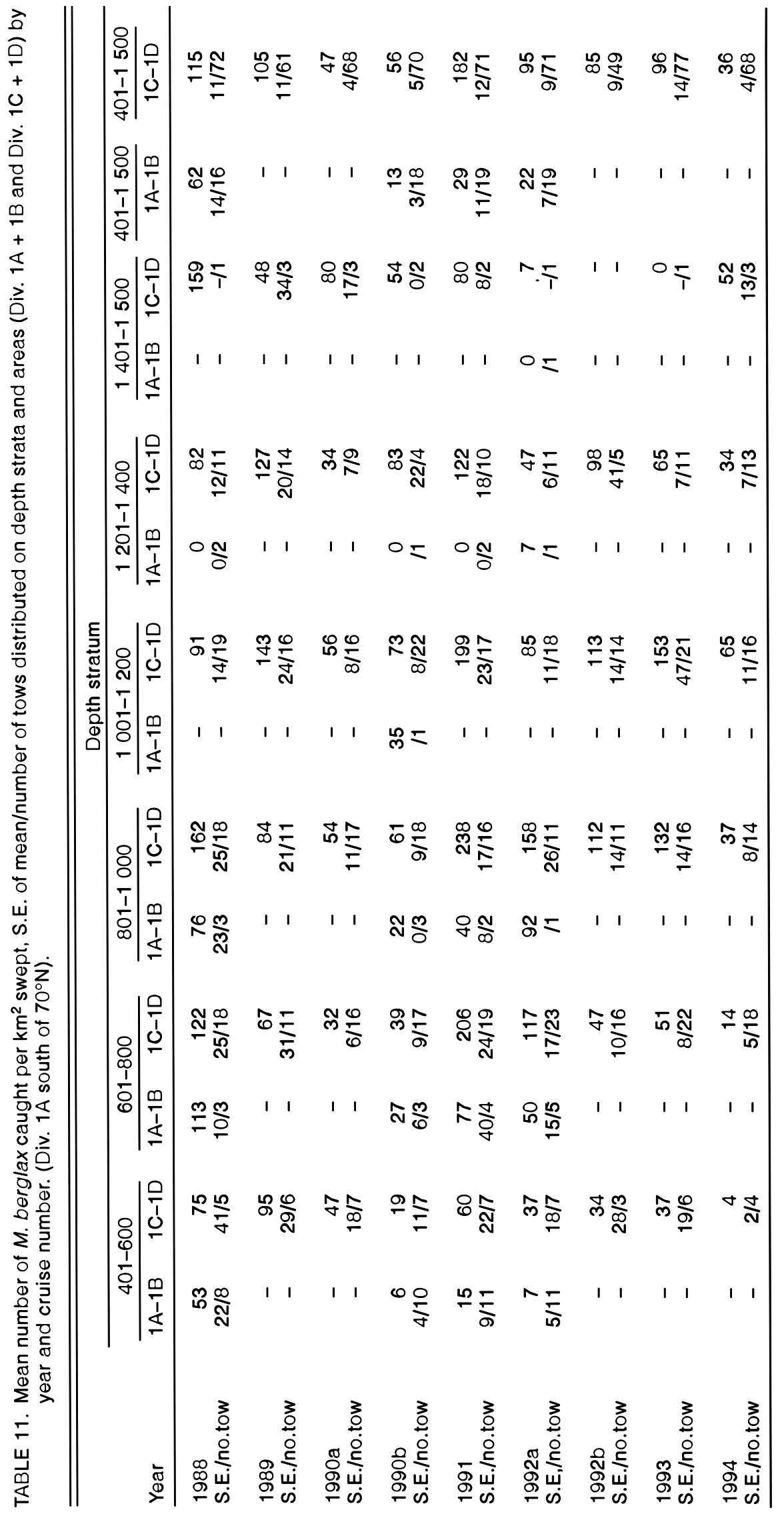



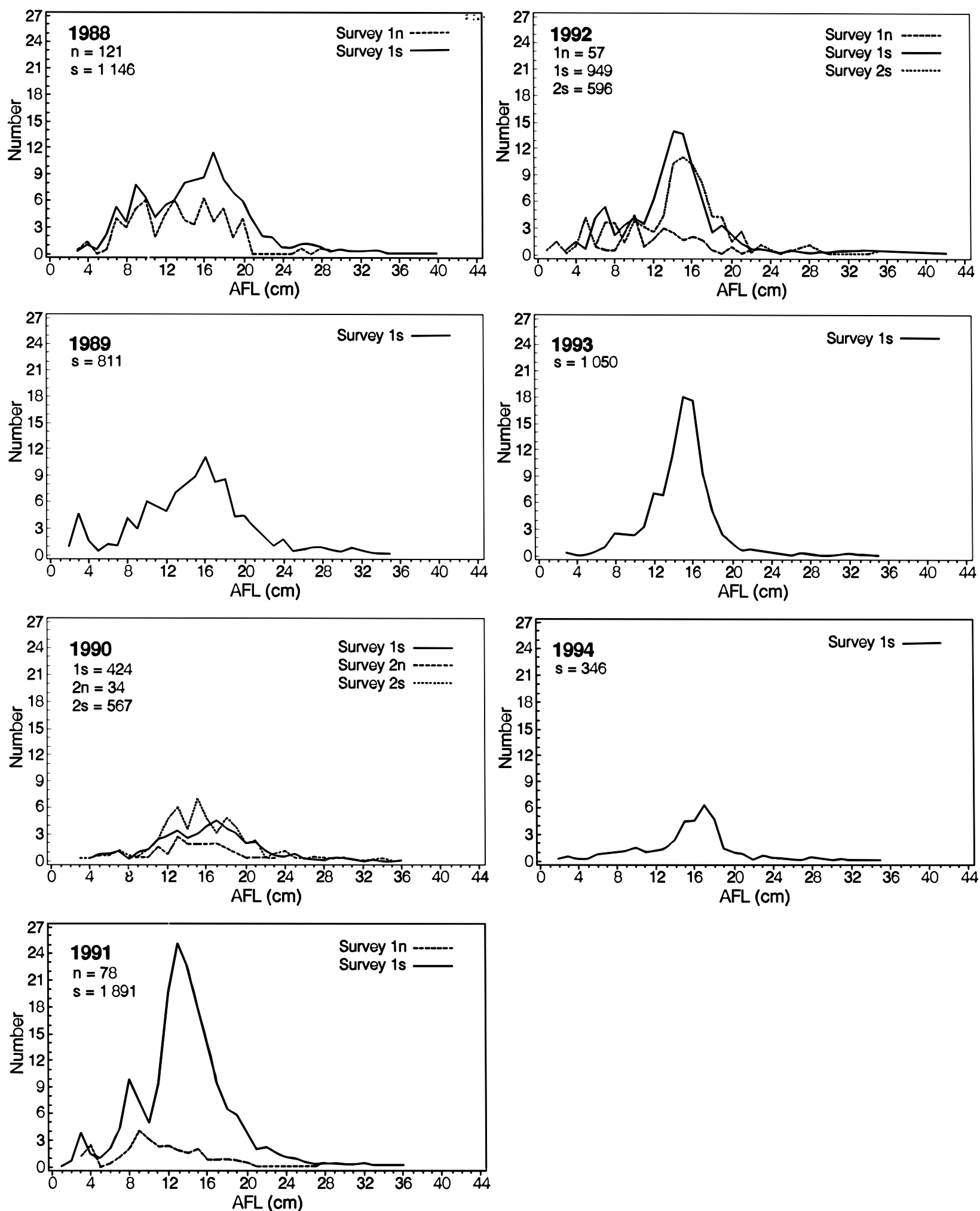

Fig. 11. Length distribution (AFL, 1-cm groups) of $M$. berglax collected in numbers per $\mathrm{km}^{2}$ swept in Div. 1A+1B ( $\mathrm{n}$ ) and Div. $1 \mathrm{C}+1 \mathrm{D}(\mathrm{s})$ at depths $>400 \mathrm{~m}$ in the period 1988-94. 
TABLE 12. Mean preanal fin length ( $\mathrm{AFL} \mathrm{cm}$ )-at-age; minimum and maximum length-at-age, number of observations (n) and Standard Error of mean (S.E.) for M. berglax.

\begin{tabular}{|c|c|c|c|c|c|c|c|c|c|c|}
\hline \multirow[b]{2}{*}{ Age } & \multicolumn{5}{|c|}{ Males } & \multicolumn{5}{|c|}{ Females } \\
\hline & Length & Min. & Max. & $\mathrm{n}$ & S. E. & Length & Min. & Max. & $n$ & S.E. \\
\hline 3 & - & - & - & - & - & 7.17 & 6.5 & 7.5 & 3 & .333 \\
\hline 4 & 8.11 & 6.5 & 11.0 & 9 & .431 & 7.75 & 5.0 & 9.5 & 6 & .642 \\
\hline 5 & 9.71 & 7.0 & 12.5 & 7 & .616 & 10.16 & 9.0 & 13.0 & 16 & .218 \\
\hline 6 & 11.88 & 10.0 & 13.0 & 8 & .430 & 12.40 & 10.0 & 15.0 & 15 & .346 \\
\hline 7 & 14.42 & 10.5 & 17.5 & 32 & .262 & 14.33 & 12.5 & 18.5 & 18 & .375 \\
\hline 8 & 16.03 & 14.0 & 18.5 & 34 & .197 & 16.39 & 14.0 & 19.0 & 31 & .247 \\
\hline 9 & 17.69 & 15.0 & 21.0 & 31 & .248 & 17.61 & 16.0 & 19.5 & 22 & .257 \\
\hline 10 & 18.74 & 16.5 & 21.5 & 23 & .279 & 18.86 & 15.0 & 22.0 & 21 & .375 \\
\hline 11 & 20.29 & 19.0 & 21.5 & 14 & .201 & 21.03 & 16.5 & 24.5 & 15 & .527 \\
\hline 12 & 20.13 & 19.0 & 21.5 & 4 & .657 & 23.29 & 21.0 & 29.5 & 7 & 1.138 \\
\hline 13 & 22.00 & 21.5 & 22.5 & 2 & .500 & 23.89 & 19.0 & 27.0 & 9 & .798 \\
\hline 14 & - & - & - & - & - & 27.23 & 25.0 & 28.5 & 11 & .333 \\
\hline 15 & - & - & - & - & - & 28.50 & 27.0 & 30.0 & 5 & .500 \\
\hline 16 & - & - & - & - & - & 29.70 & 28.0 & 35.5 & 5 & 1.463 \\
\hline 17 & - & - & - & - & - & 28.50 & 28.5 & 28.5 & 2 & .000 \\
\hline 18 & - & - & - & - & - & 31.50 & 31.5 & 31.5 & 1 & - \\
\hline 19 & - & - & - & - & - & 35.00 & 35.0 & 35.0 & 1 & - \\
\hline
\end{tabular}

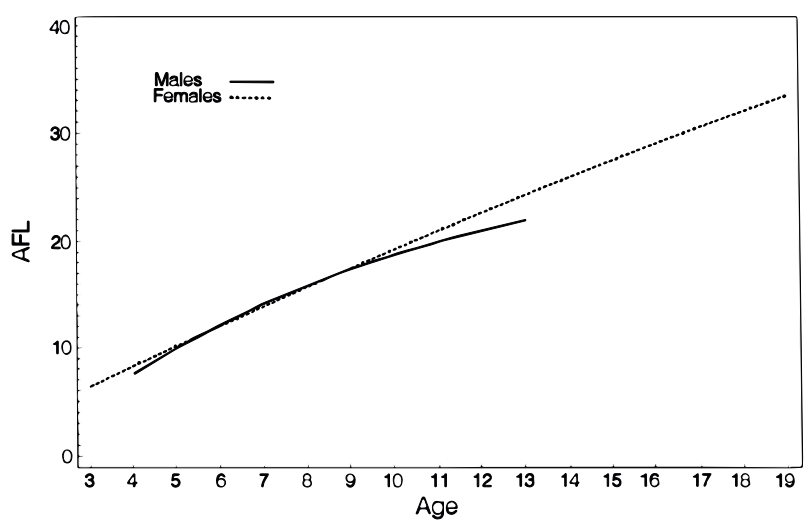

Fig. 12. Age-length relationship (AFL $\mathrm{cm})$ for M. berglax at West Greenland fitted to a von Bertalanffy growth curve.

von Bertalanffy and Gompertz growth models showed, as for $C$. rupestris, that the von Bertalanffy and Gompertz growth models fitted data significantly better $(P<0.05)$ than the Polynomial regression for males, while no significant improvement in the data fit to the model was obtained by going from the simple Polynomial regression model to the more complex von Bertalanffy or Gompertz models, for females. The Gompertz model fitted mean size-atage data for males a little better compared to the von Bertalanffy model, in terms of slightly smaller residuals in the non-linear least square procedure (Anon., 1985), while the von Bertalanffy model fitted data for females substantially better than the Gompertz model. Until age 10 the size-at-age were

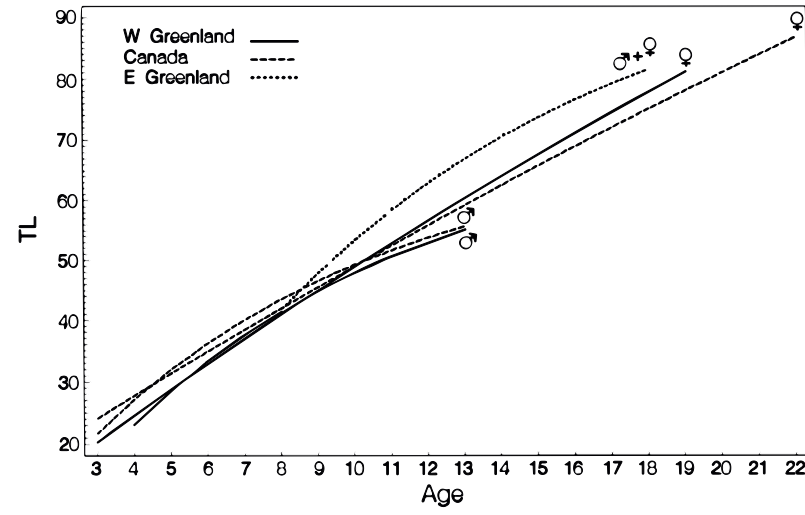

Fig. 13. Age-length relationship ( $T L \mathrm{~cm}$ ) for M. berglax at West Greenland, Canada (Savvatimsky, 1994) and East Greenland (sexes combined) (Kosswig, MS 1979) fitted to a von Bertalanffy growth curve.

the same for males and females. After that the sizeat-age for males was lower than for females (Fig. 12), which was also observed by Savvatimsky (1994) (Fig. 13). To make data comparable to other studies on growth of $M$. berglax in the Northwest Atlantic, the conversion factor previously obtained (Table 4) was used to estimate the following von Bertalanffy relationships between TL and age: TL $=70.655 \times(1-1.107 \times \exp (-0.125 \times$ age $))$ and $\mathrm{TL}=$ $252.180 \times(1-0.973 \times \exp (-0.019 \times$ age $))$, respectively. Size-at-age reported from East Canada (Savvatimsky, 1994) and West Greenland were close to each other, while size-at-age at East Greenland (Kosswig, MS 1979) seemed to be somewhat higher above age 9 (Fig. 13). As for C. rupestris, very little 
work has been done on this species on intercalibration between age readers from different laboratories, and the differences in mean size-at-age observed between different investigations could be caused by different interpretation of growth zones.

A total of 533 stomachs, of which $21 \%$ were empty, were sampled at different times of the year (Table 2). The percentage of empty stomachs was lowest during August/September, on average 15\%, however, this varied from $8 \%$ to $24 \%$ during the three years sampling was carried out. The percentage of empty stomachs was highest in December (36\%).
Overall, 58 different food items or groups of food items were identified in the stomachs, representing nine major animal classes or super-classes (Table 13). Cephalopoda, Pisces, Crustacea and Echinodermata were the most important prey by weight, whereas Crustacea and Polychaeta were the most important in terms of percentage occurrence. Generally, the food composition was rather stable throughout the year. There was, however, a tendency towards an increase in percentage occurrence of Crustacea from $44 \%$ in June to around $70 \%$ in August-December. This increase was mainly due to an increase in the occurrence of Mysidacea and

TABLE 13. Food of $M$. berglax expressed as weight percentage and frequency of occurrence at different time of the year.

\begin{tabular}{|c|c|c|c|c|c|c|c|c|}
\hline \multirow[b]{2}{*}{ Food item } & \multicolumn{4}{|c|}{ Weight Percentage } & \multicolumn{4}{|c|}{ Frequency of Occurrence } \\
\hline & Jun & Aug/Sep & Nov/Dec & All & Jun & Aug/Sep & Nov/Dec & All \\
\hline Coelenterata & & 0.38 & & 0.28 & & 1.05 & & 0.71 \\
\hline Polychaeta & 12.27 & 10.07 & 18.08 & 11.15 & 74.03 & 71.43 & 64.29 & 70.95 \\
\hline Mollusca & 0.04 & & & 0.01 & 2.60 & & & 0.48 \\
\hline Gastropoda & 1.55 & 0.37 & 16.73 & 1.99 & 6.49 & 2.44 & 8.93 & 4.05 \\
\hline Bivalvia & 0.18 & 0.75 & 0.49 & 0.63 & 10.39 & 19.86 & 16.07 & 17.62 \\
\hline Cephalopoda & 4.56 & 34.73 & 0.65 & 26.41 & 7.79 & 3.83 & 1.79 & 4.29 \\
\hline Crustacea (total) & 9.61 & 17.16 & 13.51 & 15.49 & 44.16 & 72.47 & 71.43 & 67.14 \\
\hline Ostracoda & & 0.01 & & 0.01 & & 0.35 & & 0.24 \\
\hline Copepoda & & 0.00 & & 0.00 & & 0.35 & & 0.24 \\
\hline Calanoida & 0.04 & 0.16 & 0.12 & 0.14 & 1.30 & 11.50 & 5.36 & 8.81 \\
\hline Mysidacea & 0.47 & 2.24 & 1.14 & 1.83 & 5.19 & 11.50 & 12.50 & 10.48 \\
\hline Isopoda & & 0.01 & 0.69 & 0.07 & & 0.70 & 5.36 & 1.19 \\
\hline Hyperiidae unident. & 0.04 & 0.18 & & 0.14 & 2.60 & 7.67 & & 5.71 \\
\hline Parathemisto & 0.08 & 0.19 & & 0.15 & 1.30 & 6.97 & & 5.00 \\
\hline Gammaridea & 1.49 & 1.62 & 3.51 & 1.76 & 15.58 & 32.40 & 35.71 & 29.76 \\
\hline Euphausiacea & & & 0.04 & 0.00 & & & 1.79 & 0.24 \\
\hline Cumacea & & 0.02 & 1.47 & 0.14 & & 1.74 & 14.29 & 3.10 \\
\hline Natantia unident. & 5.54 & 3.87 & 0.82 & 3.91 & 3.90 & 3.14 & 3.57 & 3.33 \\
\hline Pandalus sp. & & 1.27 & & 0.93 & & 0.35 & & 0.24 \\
\hline Pandalus borealis & & 2.37 & & 1.74 & & 1.05 & & 0.71 \\
\hline Anomura & 0.87 & 4.03 & 1.31 & 3.23 & 3.90 & 4.53 & 3.57 & 4.29 \\
\hline Crustacea unident. & 1.08 & 1.19 & 4.41 & 1.44 & 23.38 & 36.24 & 37.50 & 34.05 \\
\hline Asteroidea & 0.75 & & 0.08 & 0.14 & 1.30 & & 1.79 & 0.48 \\
\hline Ophiuroidea & 3.26 & 1.54 & 6.08 & 2.24 & 19.48 & 8.36 & 14.29 & 11.19 \\
\hline Echinoidea & 2.28 & 3.53 & 18.94 & 4.63 & 12.99 & 13.59 & 14.29 & 13.57 \\
\hline Holothuroidea & 20.21 & 5.03 & 15.47 & 8.64 & 23.38 & 5.23 & 21.43 & 10.71 \\
\hline Crinoidea & & 0.00 & & 0.00 & & 0.35 & & 0.24 \\
\hline Chaetognatha & & 0.04 & & 0.03 & & 0.35 & & 0.24 \\
\hline Pisces (total) & 40.85 & 24.40 & 4.65 & 25.65 & 10.39 & 8.36 & 10.71 & 9.05 \\
\hline Bathylagus euryops & & 3.77 & & 2.78 & & 0.70 & & 0.48 \\
\hline Synaphobranchus kaupi & & 1.43 & & 1.05 & & 0.35 & & 0.24 \\
\hline Lycodes sp. & & 1.12 & & 0.82 & & 0.35 & & 0.24 \\
\hline Sebastes sp. & & 4.74 & & 3.49 & & 1.74 & & 1.19 \\
\hline Triglops sp. & & 3.38 & & 2.49 & & 0.70 & & 0.48 \\
\hline Careproctus reinhardti & & 2.02 & & 1.48 & & 0.35 & & 0.24 \\
\hline Macrouridae & 38.14 & & & 6.82 & 1.30 & & & 0.24 \\
\hline Pisces sp. & 2.71 & 7.94 & 4.65 & 6.72 & 10.39 & 5.92 & 10.71 & 7.38 \\
\hline Unidt. organic mat. & 4.42 & 1.98 & 5.31 & 2.70 & 25.97 & 14.29 & 14.29 & 16.43 \\
\hline All & 100 & 100 & 100 & 100 & & & & \\
\hline Stomachs & 77 & 287 & 56 & 420 & 77 & 287 & 56 & 420 \\
\hline
\end{tabular}


Gammaridea. The weight percentage of Pisces fell from $41 \%$ in June to $5 \%$ in December, but these figures were based on few observations. The percentage occurrence was stable, around 10\%, throughout the year.

The importance of Crustacea and Polychaeta as food declined with increasing fish size, while the importance of Pisces and Cephalopoda increased drastically with size, both in terms of weight percentage and percentage occurrence (Table 14). The only Crustacea which increased in percentage oc- currence with fish size were Mysidacea, Natantia and Anomura.

Polychaeta, Natantia and Ophiura sp. were the most frequent prey items off East Canada, occurring in $21 \%, 18 \%$ and $18 \%$ of the stomachs, respectively (Konstantinov and Podrazhanskaya, 1972). Savvatimsky (1969) found that Echinodermata dominated both at Labrador and Newfoundland, and that benthic Mollusca, benthic Crustacea and Pisces were also important, but the importance of the different prey groups varied between the areas. The

TABLE 14. Food of $M$. berglax expressed as weight percentage and frequency of occurrence at different length groups preanal fin length.

\begin{tabular}{|c|c|c|c|c|c|c|}
\hline \multirow[b]{2}{*}{ Food item } & \multicolumn{3}{|c|}{ Weight percentage } & \multicolumn{3}{|c|}{ Frequency of occurrence } \\
\hline & $<12 \mathrm{~cm}$ & $12-20 \mathrm{~cm}$ & $>20 \mathrm{~cm}$ & $<12 \mathrm{~cm}$ & $12-20 \mathrm{~cm}$ & $>20 \mathrm{~cm}$ \\
\hline Coelenterata & & 0.16 & 0.36 & & 0.85 & 1.67 \\
\hline Polychaeta & 31.44 & 20.85 & 4.15 & 70.40 & 77.02 & 48.33 \\
\hline Mollusca & & 0.02 & & & 0.85 & \\
\hline Gastropoda & 0.41 & 4.46 & 0.49 & 2.40 & 3.83 & 8.33 \\
\hline Bivalvia & 3.12 & 1.10 & 0.22 & 18.40 & 19.57 & 8.33 \\
\hline Cephalopoda & & 7.04 & 39.79 & & 5.53 & 8.33 \\
\hline Crustacea (total) & 41.34 & 23.28 & 9.48 & 82.20 & 63.40 & 48.33 \\
\hline Ostracoda & & 0.02 & & & 0.43 & \\
\hline Copepoda & & 0.01 & & & 0.43 & \\
\hline Calanoida & 3.39 & 0.11 & 0.01 & 20.00 & 4.68 & 1.67 \\
\hline Mysidacea & 4.07 & 4.17 & 0.25 & 4.80 & 13.62 & 10.00 \\
\hline Isopoda & 0.27 & 0.16 & & 1.60 & 1.28 & \\
\hline Hyperiidae unident. & 1.49 & 0.25 & 0.01 & 6.40 & 6.38 & 1.67 \\
\hline Parathemisto & 1.22 & 0.27 & 0.03 & 5.60 & 5.11 & 3.33 \\
\hline Gammaridea & 15.04 & 3.14 & 0.32 & 47.20 & 25.96 & 8.33 \\
\hline Euphausiacea & & & 0.01 & & & 1.67 \\
\hline Cumacea & 0.81 & 0.33 & & 4.00 & 3.40 & \\
\hline Natantia unident. & 2.17 & 5.37 & 3.06 & 0.80 & 2.98 & 10.00 \\
\hline Pandalus sp. & & & 1.57 & & & 1.67 \\
\hline Pandalus borealis & & 4.62 & & & 1.28 & \\
\hline Anomura & 0.14 & 2.46 & 3.85 & 0.80 & 4.68 & 10.00 \\
\hline Crustacea unident. & 12.74 & 2.37 & 0.37 & 53.60 & 28.09 & 16.67 \\
\hline Asteroidea & & 0.02 & 0.22 & & 0.43 & 1.67 \\
\hline Ophiuroidea & 1.63 & 3.10 & 1.72 & 9.60 & 11.06 & 15.00 \\
\hline Echinoidea & 0.54 & 7.22 & 3.18 & 2.40 & 14.47 & 33.33 \\
\hline Holothuroidea & 5.42 & 16.46 & 3.84 & 1.60 & 14.89 & 13.33 \\
\hline Crinoidea & & 0.01 & & & 0.43 & \\
\hline Chaetognatha & & & 0.05 & & & 1.67 \\
\hline Pisces (total) & 9.35 & 11.36 & 35.39 & 4.00 & 5.96 & 31.67 \\
\hline Bathylagus euryops & & 2.61 & 3.00 & & 0.43 & 1.67 \\
\hline Synaphobranchus kaupi & & & 1.77 & & & 1.67 \\
\hline Lycodes sp. & & & 1.38 & & & 1.67 \\
\hline Sebastes sp. & & 0.30 & 5.65 & & 0.43 & 6.67 \\
\hline Triglops sp. & & 1.45 & 3.25 & & 0.43 & 1.67 \\
\hline Careproctus reinhardti & & & 2.48 & & & 1.67 \\
\hline Macrouridae & & & 11.42 & & & 1.67 \\
\hline Pisces sp. & 9.35 & 7.00 & 6.44 & 4.00 & 5.11 & 23.33 \\
\hline Unidt. organic mat. & 6.78 & 4.94 & 1.11 & 12.80 & 19.15 & 13.33 \\
\hline All & 100 & 100 & 100 & & & \\
\hline Stomachs & 125 & 235 & 60 & 125 & 235 & 60 \\
\hline
\end{tabular}


same prey groups were dominant at eastern Grand Bank (Savvatimsky, 1984, 1989b). Off northwest Norway Crustacea, especially Amphipoda, was by far the most dominant class, occurring in $42 \%$ of the stomachs, while Polychaeta, Mollusca, Echinodermata and Pisces were of almost equal importance, occurring in about $5 \%$ of the stomachs (Eliassen and Jobling, 1985). As in the present study, Savvatimsky (1989b) observed a change in diet with size. Crustacea and Polychaeta became less important with increasing fish size while Pisces, Natantia and Anomura became more important.

Based on investigations covering most of the North Atlantic, it may be concluded that $M$. berglax is an opportunistic feeder, feeding on a large number of different prey items which it finds mainly on the bottom. Hureau et al. (1979) therefore categorized $M$. berglax as a benthic feeding type, eating less than $30 \%$ pelagic food.

Trachyrhynchus murrayi Günther, 1887. (Murray's longsnout grenadier, Roughnose grenadier)

Trachyrhynchus murrayi occurs in the central part of the North Atlantic (Geistdoerfer, 1986). At West Greenland it was fairly common $(n=192)$ with up to 11 specimens caught in a single haul. It was found between $63^{\circ} 03^{\prime} \mathrm{N}$ and $64^{\circ} 49^{\prime} \mathrm{N}$ at depths from 775 to $1409 \mathrm{~m}$ and temperatures ranging from 3.1 to $3.8^{\circ} \mathrm{C}$ (Fig. 14). Of the 56 specimens examined, $47 \%$ were male.

Fish length, in all surveys combined, ranged from 7.0 to $25.0 \mathrm{~cm}$ AFL with most fish around 15$21 \mathrm{~cm}$ and a primary mode at 19-20 cm (Fig. 9). AFL and TL were highly correlated $(P<0.01)$, and the relationship was estimated to $T L=3.985+A F L$ $\times 2.238$ (Table 4).

Nezumia aequalis (Günther, 1878). (Common Atlantic grenadier)

Nezumia aequalis is widely distributed in the North Atlantic, from northern Angola to south of Iceland and in the Mediterranean Sea in the east, and from northern Brazil to the Davis Strait in the west at depths between 200 and 1000 m (Iwamoto, 1990). Nezumia aequalis was not caught during the 1987-94 surveys, but a single specimen, 28.5 $\mathrm{cm}$ TL, caught at $63^{\circ} 24^{\prime} \mathrm{N} 53^{\circ} 10^{\prime} \mathrm{W}$ at a depth of 860 $\mathrm{m}$ was reported by Jensen (1948). (Fig. 8).

Nezumia bairdi (Goode and Bean, 1877). (Common grenadier, Marlin-spike)

Nezumia bairdi is distributed along the eastern coast of North America (Iwamoto, 1990; Parsons, 1976), at depths between 16 and $2285 \mathrm{~m}$ (Scott and Scott, 1988). It was recorded for the first time at West Greenland during the 1987-94 surveys between $63^{\circ} 46^{\prime} \mathrm{N}$ and $65^{\circ} 02^{\prime} \mathrm{N}$ at depths from 690 to 1

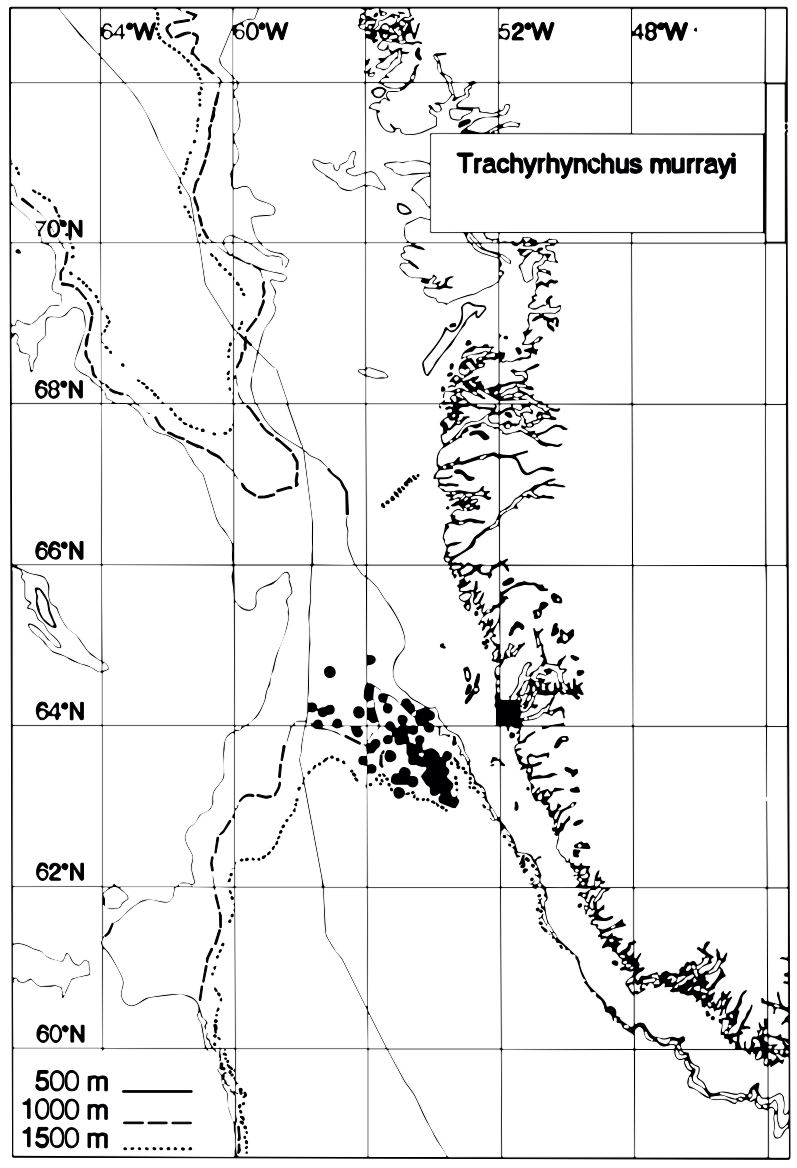

Fig. 14. Distribution of hauls in which T. murrayi was caught in the surveys of 1987-94.

$169 \mathrm{~m}$ and temperatures ranging from 3.2 to $4.0^{\circ} \mathrm{C}$ ( $n=35$ ) (Fig. 8). According to Parsons (1976) it is most abundant at depths between 500 and $775 \mathrm{~m}$ at temperatures between $3^{\circ} \mathrm{C}$ and $4^{\circ} \mathrm{C}$. Savvatimsky (1989a) observed maximum catches off the east coast of Canada at 500-700 m, however, temperatures were as high as $7-8^{\circ} \mathrm{C}$. Of the 8 specimens examined, 7 were female. Savvatimsky (1989a) also found a dominance of females, $73.4 \%(n=428)$, in the most northern part of his investigation area $\left(55^{\circ} \mathrm{N}\right)$.

Fish length, for all surveys combined, ranged from 5.0 to $10.0 \mathrm{~cm} \mathrm{AFL,} \mathrm{with} \mathrm{an} \mathrm{fairly} \mathrm{even} \mathrm{distri-}$ bution between the length groups (Fig. 9). The relationship between TL and AFL and was estimated to $\mathrm{TL}=13.967+\mathrm{AFL} \times 2.351$ (Table 4$)$.

Gadomus Iongifilis (Goode and Bean, 1986). (Threadfin grenadier)

Gadomus longifilis is distributed in the eastern Atlantic off the Azores, Madeira and Morocco northward to northern Portugal, and in the Caribbean in 
the Western Atlantic at depths between 620 and $2165 \mathrm{~m}$ (Geistdoerfer, 1986). A single specimen, $17 \mathrm{~cm} \mathrm{TL}$, was observed for the first time at West Greenland at $64^{\circ} 47^{\prime} \mathrm{N} 56^{\circ} 05^{\prime} \mathrm{W}$ at $891 \mathrm{~m}$ and at a temperature of $3.4^{\circ} \mathrm{C}$ (Fig. 8).

\section{Acknowledgements}

I thank Dr. J. Nielsen, Zoological Museum of the University of Copenhagen, for constructive comments on an earlier draft of the manuscript and for the identification and verification of some of the species. I also thank the scientific personnel and the crew on board Shinkai Maru, for assisting in collecting data and material.

\section{References}

ANON. 1985. SAS Users Guide: Statistics, Version 5 Edition. Cary, NC USA: SAS Institute Inc. 956 p.

ATKINSON, D. B. 1981. Partial length as a replacement for total length in measuring grenadiers. J. Northw. Atl. Fish. Sci., 2: 53-56.

1989. Weight-length relationships of roundnose grenadier (Coryphaenoides rupestris Gunn.) in different areas of the North Atlantic. Fish. Res., 7: 65-72.

1991. Relationships between pre-anal fin length and total length of roughhead grenadier (Macrourus berglax Lacépède) in the Northwest Atlantic. J. Northw. Atl. Fish. Sci., 11: 7-9.

1995. The biology and fishery of roundnose grenadier (Coryphaenoides rupestris, Gunnerus 1765) in the North West Atlantic. In: Deep-Water Fisheries of the North Atlantic Ocean Slope, A. G. Hopper (Ed). Kluwer Academic Publishers, Dordrect. 51111.

ATKINSON, D. B., W. R. BOWERING, D. G. PARSONS, Sv.Aa. HORSTED, and J. P. MINET. 1982. A review of the biology and fisheries for roundnose grenadier, Greenland halibut and northern shrimp in Davis Strait. NAFO Sci. Coun. Studies, 3: 7-27.

ATKINSON, D. B., and D. POWER. MS 1987. Distribution of roughhead and roundnose grenadiers in the Northwest Atlantic. NAFO SCR Doc., No. 94, Serial No. $\mathrm{N} 1398,28 \mathrm{p}$.

BOJE, J., and N.-R. HAREIDE. MS 1993. Trial deepwater longline fishery in the Davis Strait, May-June 1992. NAFO SCR Doc., No. 53, Serial No. N2236, 6 p.

CHUMAKOV, A. K., and P. I. SAVVATIMSKY. MS 1987. Distribution of Greenland halibut and roundnose grenadier in the Northwest Atlantic in relation to hydrographic conditions in 1968-1986. NAFO SCR Doc., No. 93, Serial No. N1397, 38 p.

DUSCHENKO, V. V. 1985. The formation of the commercial stock of the North Atlantic rock grenadier. In: Behavior of commercial fishes. P.A. Moiseev (ed). Collection of scientific works of VINRO: 141-154. (Translated from Russian). Fish. Res. Bd. Can., Transl. Ser. No. 5340.

ELIASSEN. J-E., and M. JOBLING. 1985. Food of the roughhead grenadier, Macrourus berglax, Lacepede in North Norwegian waters. J. Fish Biol., 26: 367376.

GEISTDOERFER, P. 1979. New data on the reproduction of Macrourids (Teleostei, Gadiformes). Sarsia, 64:
$109-112$.

1986. Macrouridae. In: Fishes of the North-eastern Atlantic and the Mediterranean. Whitehead, P. J. P., M.-L. Bauchot, J.-C. Hureau, J. Nielsen and E. Tortonese (eds.). UNESCO. Vol II, 644-676.

GORDON, J. D. M. MS 1978. Some notes on the biology of the roundnose grenadier Coryphaenoides rupestris to the West of Scotland. ICES C.M. Doc., No. G:40, $12 \mathrm{p}$.

GRIGOREV, G. V. 1972. Reproduction of Macrourus rupestris Gunner of the Northern Atlantic. Trudy PINRO, 28: 107-115. (Translated from Russian). Fish. Res. Bd. Can. Transl. Ser. No. 2529.

GUSHCHIN, A. V., and S. G. PODRAZHANSKAYA. 1984. Feeding of roundnose grenadier (Coryphaenoides rupestris) and its trophic relationships in the North Atlantic. NAFO Sci. Coun. Studies, 7: 53-59.

HAEDRICH, R. L. 1974. Pelagic capture of the epibentich rattail Coryphaenoides rupestris. Deep-Sea Research, 21: 977-979.

HUREAU, J.-C., P. GEISTDOERFER, and M. RANNOU. 1979. The ecology of deep-sea benthic fishes. Sarsia, 64: 103-108.

IWAMOTO, T. 1990. Macrouridae. In: FAO species catalogue. Vol. 10 Gadiform fishes of the world (Order Gadiformes). Cohen, D. M, T. Inada, T. Iwamoto, and N. Scialabba (eds.). FAO Fisheries Synopsis. No. 125, Vol. 10, $442 \mathrm{p}$.

JENSEN, Ad. S. 1948. Contributions to the ichthyofauna of Greenland (Macruridae). Spolia Zool. Mus. Haun., IX: 176-182.

JØRGENSEN, O., and K. AKIMOTO. MS 1991. Results of two trawl surveys in NAFO Subarea 1 in 1990. NAFO SCR. Doc., No. 50, Serial No. N1933, 14 p.

KARRER, C. 1976. Über Fischarten aus der Davisstrasse und Labradorsee. Mitt. Zool. Mus. Berlin Bd., 52, Heft 2: 371-376.

KONSTANTINOV, K. G., and S. G. PODRAZHANSKAYA. 1972. Nutrition and food interrelations of grenadier (Macrourus rupestris) and other deepwater fishes of Northwest Atlantic. Trudy PINRO, 28: 96-106. (Translated from Russian). Fish. Res. Bd. Can. Transl. Ser. No. 2537.

KOSSWIG, K. MS 1979. A note on the age and growth of the roughhead grenadier (Macrourus berglax Lacépède) at East Greenland (Dohrn Bank) in 1978. ICES C.M. Doc., No. G:59, 4 p.

KOSSWIG, K. MS 1980. A contribution on the age and growth of roundnose grenadier (Coryphaenoides rupestris GUNN) at West Greenland (NAFO Subarea 1). NAFO SCR Doc., No. 92, Serial No. N147, 5 p.

MAGNÚSSON, J. V. MS 1987. Grenadier fish in Icelandic waters. NAFO SCR Doc., No. 87, Serial No. N1341, $19 \mathrm{p}$.

MARSHALL N. B., and T. IWAMOTO. 1973. Family Macrouridae. In: Fishes of the Western North Atlantic. Cohen D. M. (ed). Mem. Sears Found. Mar. Res., 1(6): 496-665.

PARSONS, L. S. 1976. Distribution and relative abundance of roundnose, roughhead and common grenadiers in the Northwest Atlantic. ICNAF Sel. Pap., 1: 73-88.

SAVVATIMSKY, P. I. 1969. The grenadier of the North Atlantic. Trudy PINRO: 3-72. (Translated from Russian). Fish. Res. Bd. Can. Transl. Ser. No. 2879.

1972. The age of the rock grenadier in the NorthWest Atlantic and a possible influence of fisheries 
on its population numbers. Trudy PINRO, 28: 116127. (Translated from Russian). Fish. Res. Bd. Can. Transl. Ser. No. 2491.

1982. Reproduction and sex composition of the North Atlantic rock grenadier. Trudy PINRO: 32-53. (Translated from Russian). Fish. Res. Bd. Can. Transl. Ser. No. 5389

1984. Biological aspects of roughhead grenadier (Macrourus berglax) from longline catches in the eastern Grand Bank area, 1982. NAFO Sci. Coun. Studies, 7: 45-51.

1985. Diurnal vertical migrations of cod and rock grenadier in the northwest Atlantic. In: Behavior of commercial fishes. P.A. Moissev (ed). Trudy VNIRO: 66-77. (Translated from Russian). Fish. Res. Bd. Can. Transl. Ser. No. 5338.

1989a. Distribution and biology of common grenadier (Nezumia bairdi) from trawl surveys in the Northwest Atlantic. NAFO Sci. Coun. Studies, 13: 53-58.

$1989 \mathrm{~b}$. Investigations of roughhead grenadier (Macrourus berglax L.) in the Northwest Atlantic, 1967-83. NAFO Sci. Coun. Studies, 13: 59-75.
1994. Age structure of roughhead grenadier (Macrourus berglax) in the Northwest Atlantic, 1985. NAFO Sci. Coun. Studies, 20: 53-64.

SAVVATIMSKY, P. I., and D. B. ATKINSON. 1993. Lengthweight relationships of roundnose grenadier (Coryphaenoides rupestris Gunn.) in different areas of the Northwest Atlantic. NAFO Sci. Coun. Studies, 19: $71-78$.

SAVVATIMSKY, P. I., H. KOCH, AND P. ERNST. 1977. On comparison of methods of age determination of grenadiers (Macrouriformes, Pisces) of the North Atlantic. Voprosy Ikhtiolgii, 17: 324-327.

SCOTT, W. B., and M. G. SCOTT. 1988. Atlantic fishes of Canada. Can. Bull. Fish. Aquat. Sci., 219: 731 p.

WHEELER, A. 1969. The fishes of the British Isles and Northwest Europe. MacMillan and Co. Ltd. London, England, $613 \mathrm{p}$.

ZAKHAROV, G. P., and I. D. MONAKU. 1970. The distribution and biological characteristics of the rock grenadier (Macrourus rupestris) in the Davis Strait in August-September 1969. (Survey report in Russian cited in SAVVATIMSKY, 1972.) 
